\title{
Recent Advancements in the Use of Aerosol-Assisted Atmospheric Pressure Plasma Deposition
}

\author{
Fabio Palumbo ${ }^{1, *(\mathbb{D}}$, Chiara Lo Porto ${ }^{2}$, Francesco Fracassi ${ }^{1,2}$ and Pietro Favia ${ }^{1,2}$ \\ 1 Institute of Nanotechnology, National Research Council, Department of Chemistry, University of Bari “Aldo \\ Moro", Via Orabona 4, 70126 Bari, Italy; francesco.fracassi@uniba.it (F.F.); pietro.favia@uniba.it (P.F.) \\ 2 Department of Chemistry, University of Bari "Aldo Moro", Via Orabona 4, 70126 Bari, Italy; \\ chiara.loporto@uniba.it \\ * Correspondence: fabio.palumbo@cnr.it
}

Received: 2 April 2020; Accepted: 26 April 2020; Published: 29 April 2020

\begin{abstract}
Atmospheric pressure plasma allows for the easy modification of materials' surfaces for a wide range of technological applications. Coupling the aerosol injection of precursors with atmospheric pressure plasma largely extends the versatility of this kind of process; in fact solid and, in general, scarcely volatile precursors can be delivered to the plasma, extending the variety of chemical pathways to surface modification. This review provides an overview of the state of the art of aerosol-assisted atmospheric pressure plasma deposition. Advantages (many), and drawbacks (few) will be illustrated, as well as hints as to the correct coupling of the atomization source with the plasma to obtain specific coatings. In particular, the deposition of different organic, hybrid inorganic-organic and bioactive nanocomposite coatings will be discussed. Finally, it will be shown that, in particular cases, unique core-shell nanocapsules can be obtained.
\end{abstract}

Keywords: aerosol; plasma deposition; aerosol-assisted atmospheric pressure plasma; nanocomposite coatings

\section{Introduction}

The term aerosol refers to a mixture where liquid or solid particles are suspended in a gaseous medium for a time long enough to be observed. This differs from hydrosol, since the latter concerns suspension in a liquid. The size of the suspended particles is below $100 \mu \mathrm{m}$, and typically below tens of microns, with a density below 1\% [1]. Common natural or anthropogenic aerosols include clouds, fog, haze, geyser steam and smoke. However, for several applications it is useful to produce aerosol in a controlled way. Aerosol generation finds applications in pesticide spraying [2], combustion technology [3], drug administration [4] and in the fundamentals of atmospheric aerosols [1].

If we focus on aerosol formed by liquid droplets, three main approaches can be considered: ultrasonic generation, pneumatic jet, and electrostatic atomization. The aerosol formation mechanism is different depending on the method, droplet characteristics and distribution.

Ultrasound aerosol generator. A piezoelectric transducer is placed underneath the liquid feed, through which a carrier gas passes. The power of the transducer and the gas carrier flow rate do not affect the droplet size, but the amount of aerosol produced is altered. The atomized droplet size is commonly in the range $1-10 \mu \mathrm{m}$.

Pneumatic generator. A compressed gas is generally transversally introduced through a nozzle towards a liquid stream, spreading the fluid in droplets. The size distribution of the droplets is somehow higher than the ultrasonic method. However, by correctly designing the nozzle and the generator's head geometry, a narrow size distribution can be obtained with an average droplet diameter below $1 \mu \mathrm{m}$. 
Electrostatic aerosol atomization. In this case, either the feed is atomized by ultrasound and a high electric field is applied to the aerosol or, alternatively, the electric field is directly applied to a nozzle, causing the atomization of the liquid into charged droplets.

Aerosol generation can be easily and advantageously coupled to Chemical Vapour Deposition (CVD). CVD is a widely used process for the formation of a solid film on a substrate. Precursor species are admitted into the reaction chamber, where the substrate is placed, often together with an inert carrier gas, sometimes in vacuum conditions. The reactions of the gaseous precursor occur either in the gas phase or on the surface of the substrate, triggered by energy, light or heat [5].

A main concern regarding CVD techniques is the selection and delivery of suitable chemical precursors, mainly due to difficulties in handling solid and, in general, low vapour pressure chemicals. Aerosol-assisted CVD (AA-CVD) offers a way to overcome such issues, since with this approach there is virtually no limit to the nature of stable precursors that can be used in coating technology, except the eventual handling hazard and compatibility with the reactor materials. In fact, the precursor, liquid or solid, can be injected pure or dissolved in a solvent via atomization. Furthermore, AA-CVD allows for a high deposition rate due to the high mass transport rate of the precursor, easy multi-precursor injection with good stoichiometric control, and easy processing at atmospheric pressure. The latter leads to a subsequent cost reduction, due to the limited requirement for pumping systems and time. A possible scheme of a typical AA-CVD process is reported in Figure 1. The main parameters influencing the growth process are substrate temperature, the presence of solvents or additives in the sprayed liquid, timing (both duration and activation energy pulsing) and flow rate.

This review is not meant to detail the different versions of the AA-CVD process-a more exhaustive description can be found elsewhere [5-7]. Here, we only refer to aerosol-assisted metalorganic CVD, when metalorganic compounds are admitted by atomization; aerosol-assisted combustion CVD, when the aerosol is injected in a flame; electrostatic spray-assisted vapour deposition (ESAVD) and electrostatic assisted aerosol jet deposition (EAAJD), both involving the charging of the atomized precursor with respect to the substrate [5,7]. Concerning these last two setups, in ESAVD [8] the charging is simultaneous to the atomization, while in EAAJD [9], the two events are separated.

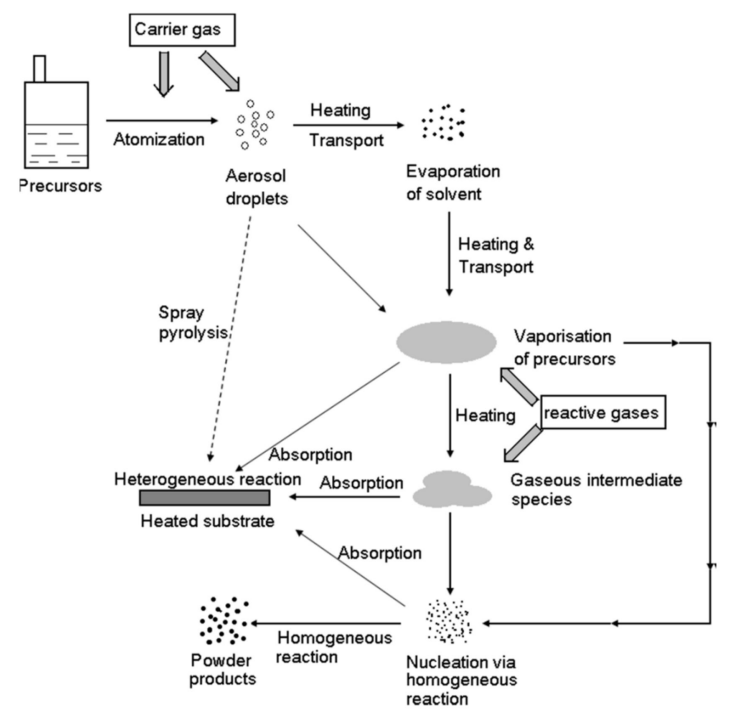

Figure 1. General scheme of Chemical Vapour Deposition (CVD) assisted by aerosol. Once atomized, the droplet loses the solvent (if present) and the precursor diffuses to the heated substrate, where it is chemisorbed, giving origin to the coating (heterogeneous reaction). In a parallel path the precursor reacts through homogeneous reactions in the gas phase, then species adsorb onto the substrate, or through an extensive reaction in the gas phase, to form powder products. Reprinted with permission from [7]. Copyright 2006 John Wiley \& Sons, Inc. 
A further version of AA-CVD can be considered, which is the object of this review. When the precursor activation energy in CVD is provided by a plasma, or an electrical discharge, the process is known as "plasma deposition" or Plasma-Enhanced CVD (PE-CVD) [10]. Plasma deposition can be suitably coupled to the aerosol injection of the coating precursor, with advantages due both to the versatility of plasma processing and the availability of a broader range of chemical routes.

This review is organized as follows: in the rest of the introduction, an overview of plasma technology and, in particular, of cold atmospheric pressure plasma is given. Then, in Section 2, the general issues of coupling aerosols and plasma for coating deposition are discussed. Sections 3 and 4 give an overview of the aerosol-assisted plasma deposition processes present in the literature, in order to prepare simple layers or nanocomposite ones, respectively.

Plasma is an ionized gas state with an equal density of positive and negative species. In nature, it is very common - in fact, typical examples are stars, solar wind, aurora borealis and lightning [11]. Plasma can be thermal (equilibrium), with a quasi-homogeneous distribution of energy amongst the degrees of freedom of the species, reaching gas temperatures as high as $10^{5} \mathrm{~K}$. Typically, thermal plasma is applied in welding, metal cutting, waste abatement, and in the production of refractory layers [12]. However thermal plasma can hardly be used on thermo-labile substrates, where cold plasma is much more adequate. Non-equilibrium cold plasma can be obtained at low pressure (usually less than 1 torr) or at atmospheric pressure [13]: a proper electric field is applied to a gas mixture, which is static but more often flowing, in reactors with a suitable configuration. The electric field transfers energy mostly to electrons that, when accelerated, trigger ionization, excitation and the breaking of chemical bonds with the consequent formation of active species. Such species are typically other free electrons, atomic and molecular radicals and ions (in ground and excited levels), and visible/ultraviolet photons. However, this highly reactive environment is maintained close to room temperature. Cold plasma processing can, therefore, be carried out to modify the surface of thermo-labile materials, or to synthetize bulky materials such as nano-powder for a broad range of technological applications. The processing of a material's surface by plasma can be divided into three categories: dry etching, plasma treatment and plasma deposition (PE-CVD). Dry etching is the ablation of substrates by the formation of volatile compounds upon their reaction with active species in the plasma. In plasma treatments, reactive $\left(\mathrm{O}_{2}, \mathrm{H}_{2} \mathrm{O}, \mathrm{H}_{2}, \mathrm{NH}_{3}, \mathrm{CF}_{4}\right.$, etc) or inert (commonly Ar) gas is activated by the plasma and the activated species react with the surface, leading to the grafting of chemical groups (such as carboxylic, amino, hydroxyl moieties), oxidation or reduction, and crosslinking in the case of polymers $[14,15]$. Plasma deposition or PE-CVD, sometimes called "Plasma Polymerization", allows for the preparation of films (with thicknesses between $10 \mathrm{~nm}$ and $1 \mu \mathrm{m}$ ) with a tuneable chemical composition and structure [10]. By PE-CVD, deposition can be achieved even from precursors that are unsuitable for conventional polymerization, such as saturated compounds like alkanes or perfluoroalkanes. Choosing the right precursors, PE-CVD coatings can be engineered to address surface properties such as wettability (even superhydrophobic and superhydrophilic), corrosion protection, hardness, the gas/vapour diffusion barrier, friction, wear resistance and resistance to bacterial colonization. PE-CVD coatings range from Teflon-like (hydrophobic surfaces) [16] to silica-like (gas/vapor barrier layers in packaging; anti-scratch coatings on plastic optics and anti-corrosion coatings) [17], and from hard anti-wear diamond-like [18] to soft, functionalized organic coatings mostly use in biomedical applications [19].

Several configurations of plasma reactors and sources have been developed; the choice is primarily driven by the useful selected pressure regime. Low pressure plasma reactors are mostly designed for material surface processing. Typically, radiofrequency power supplies at $13.56 \mathrm{MHz}$ are used in parallel-plate reactors, commonly for semiconductor and integrated circuit technology manufacture in microelectronics, but other electrode coupling configurations are available, such as inductive or microwave-driven configurations.

However, aerosol atomization sources are primarily coupled to atmospheric pressure plasma reactors. Besides Corona Discharge, Dielectric Barrier Discharge (DBD) is the most widely used electrode configuration for the generation of cold atmospheric pressure (AP) plasma. In order to reduce 
the current and, in turn, to inhibit the transition to a hot plasma (via arcing), a dielectric layer (typically alumina or quartz) covers one or both electrodes. Furthermore, the electrodes' distance is in the range of few millimetres, thus further reducing the possibility that species can have a collision frequency high enough to lead to thermalization and a consequent increase in neutral temperature. This could be a limitation, since the process can be better optimized for thinner (laminar) substrates than for 3D complex shape samples, but we will describe how to face this issue presently. A further trick to limit current increase is by using an $\mathrm{AC}$ power supply, typically in the $\mathrm{KHz}$ range, often in a pulsed regime, with fast time rise pulses of micro/nanoseconds. In Figure 2, three typical electrode configurations for DBDs are reported [19].

To overcome the main limitation of the DBD processing of materials, namely the treatment of 3D objects, and also to extend the range of possible applications of AP plasma, jet source configurations can be suitably designed. In this setup, the plasma is ignited between two electrodes in a remote position and, hence, it expands towards the substrate placed out of the inter-electrode region. This setup, of which two possible configurations are depicted in Figure 3, allows for coupling with a robotized arm for automatic processing [20], or the treatment of large surfaces by mounting a suitable number of plasma jets in an array [21].

Though the low-pressure plasma processing of materials is characterized by a well-known understanding of experimental parameter handling and equipment design and standardization, AP plasma brings the advantage of the reduced cost of its equipment. In fact, a high vacuum is commonly not necessary and power supplies, even if they differ from lab to lab (and this could be an issue when comparing sources), are typically less expensive. AP cold plasma can compete in performance with low pressure plasma in surface modification processes, both in terms of polymer treatment and film deposition [22-27], and can find applications even in etching-based texturing [28], and in specific fields like waste abatement [29] or plasma medicine [19].

a

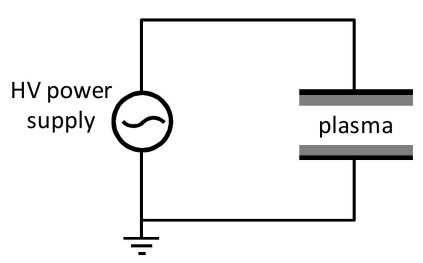

b

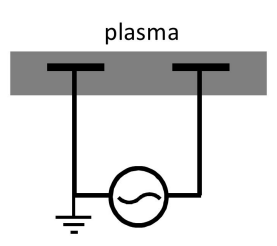

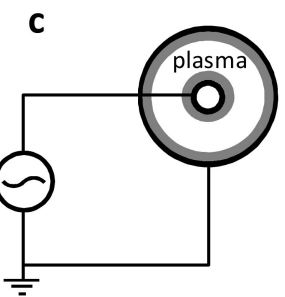

Figure 2. Three typical Dielectric Barrier Discharge (DBD) configurations: (a) parallel plate; (b) co-planar surface DBD; (c) co-axial DBD. The dielectric layer that covers the electrodes is represented in grey. Reprinted with permission from [19]. Copyright 2018 Elsevier.
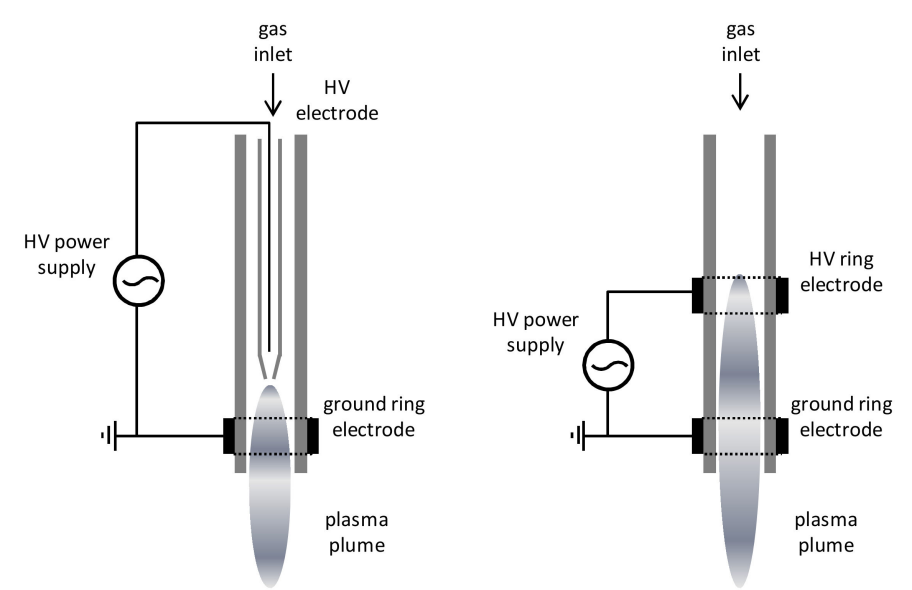

Figure 3. Design of two atmospheric pressure plasma jet (APPJ) sources. Glass (dielectric) tubes are in grey. Reprinted with permission from [19]. Copyright 2018 Elsevier. 
The implementation of AP plasma sources with atomization systems allows us to extend their applications in different fields, from high-tech agriculture to medicine and the administration of pesticides or drugs [30]. In the following sections, the advantages and disadvantages of the various coupling approaches for aerosol-assisted plasma deposition (AAPD) will be discussed.

\section{Coupling Aerosols to Plasma Deposition}

When coupling an aerosol with a plasma, some challenges, most of which still deserve deep investigation, arise. The interaction of the discharge with a fine dispersion of submicrometric liquid droplets of complex composition leads to some fundamental issues [2]:

- Modifications induced by the liquid droplets in the plasma (radiation absorption by the liquid, perturbation of the electric field);

- Modifications of the liquid droplets due to plasma (droplet charging, liquid evaporation and coalescence;

- Transport phenomena between the plasma and droplets (gas diffusion in the droplets, charge particle migration).

The comprehension of these phenomena, through further investigation, can surely improve the optimization of aerosol-assisted plasma deposition. This review will provide an assessment of the state of the art.

A list of coatings deposited by AAPD is reported in Table 1, together with possible applications. For each coating, the gas feed and the kind of plasma source is also reported, but it can be observed that coatings can be organic, inorganic or hybrid as well.

Table 1. Selected examples of aerosol-assisted plasma deposition (AAPD) deposited coatings.

\begin{tabular}{|c|c|c|c|c|}
\hline Coating Category & Reactor Set Up & Feed & Application & Ref. \\
\hline perovskite & $\begin{array}{c}\text { Microwave } \\
\text { atmospheric plasma }\end{array}$ & $\begin{array}{c}\mathrm{La}\left(\mathrm{NO}_{3}\right)_{3}, \mathrm{Sr}\left(\mathrm{NO}_{3}\right)_{2} \\
\mathrm{Mn}\left(\mathrm{NO}_{3}\right)_{2} \text { and glycine }\end{array}$ & $\begin{array}{c}\text { Electrochemical, magnetic, } \\
\text { catalytic, gas separation, } \\
\text { sensor and superconducting } \\
\text { applications }\end{array}$ & [31] \\
\hline Ceria-like & Plasma jet & cerium acetate & Corrosion protection & [32] \\
\hline $\begin{array}{l}\text { Organic coating } \\
\text { COOH rich }\end{array}$ & Plasma jet & Acrylic acid & $\begin{array}{l}\text { Wettable, good adhesive and } \\
\text { gas barrier characteristics }\end{array}$ & [33] \\
\hline Silica-like & DBD planar & $\begin{array}{l}\text { TEOS, GLYMO, MEMO, } \\
\text { PTMO in aerosol }\end{array}$ & Barrier coating & [34] \\
\hline $\begin{array}{l}\text { Bio-composite } \\
\text { coating }\end{array}$ & $\begin{array}{l}\text { Pilot scale atmospheric } \\
\text { pressure plasma } \\
\text { reactor }\end{array}$ & $\begin{array}{l}\text { Cetalkonium chloride, } \\
\text { Benzalkonium chloride and } \\
\text { Cetyl pyridinium chloride in } \\
\text { PEG or Acrylic acid (aerosol) }\end{array}$ & $\begin{array}{l}\text { Active composite coating, } \\
\text { drug delivery }\end{array}$ & [35] \\
\hline $\begin{array}{l}\text { Organic coating } \\
\text { COOH rich }\end{array}$ & DBD planar & Acrylic acid (aerosol) & Functional coating & [36] \\
\hline Organic coating & DBD planar & $\begin{array}{l}22 \text { different organic } \\
\text { precursors (aerosol) }\end{array}$ & Fundamental study & [37] \\
\hline Silica-like & DBD planar & $\begin{array}{l}\text { PDMS, HMDSO, } \\
\text { TMDSO(aerosol) }\end{array}$ & $\begin{array}{l}\text { Packaging, biomedical, } \\
\text { automotive, microelectronic }\end{array}$ & [38] \\
\hline $\begin{array}{l}\text { Fluorocarbon } \\
\text { coating }\end{array}$ & DBD planar & Fluorocarbon (aerosol) & $\begin{array}{l}\text { Hydrophobic coating on } \\
\text { PET fabrics }\end{array}$ & [39] \\
\hline Silica-like & DBD planar & HMDSO (aerosol) & Anticorrosion coating & [40] \\
\hline Organic coatings & DBD planar & AA or OCTMS (aerosol) & Functional coating & [41] \\
\hline Organic coatings & Plasma jet & $\begin{array}{c}\text { Z-TOMCATS and } \\
\text { heptadecafluorodecylacrylate }\end{array}$ & Fundamental study & [42] \\
\hline
\end{tabular}


Table 1. Cont.

\begin{tabular}{|c|c|c|c|c|}
\hline Coating Category & Reactor Set Up & Feed & Application & Ref. \\
\hline Organic coatings & $\begin{array}{l}\text { Atmospheric pressure } \\
\text { plasma }\end{array}$ & PCL diol (aerosol) & $\begin{array}{l}\text { Biodegradable polymer for } \\
\text { packaging or medical } \\
\text { sutures. }\end{array}$ & [43] \\
\hline $\begin{array}{l}\text { Fluorocarbon } \\
\text { coating }\end{array}$ & Plasma jet & HDFDA (aerosol) & fundamental & {$[44]$} \\
\hline $\begin{array}{c}\text { Hybrid } \\
\text { organic/inorganic }\end{array}$ & DBD planar & $\begin{array}{c}\text { AlCeO3 NPs in } \\
\text { HMDSO/ethanol (aerosol) }\end{array}$ & Anticorrosive coating & {$[45]$} \\
\hline Silicone-like & Plasma jet & TEOS, HMDSO (aerosol) & Hydrophobic coating & [46] \\
\hline PEG-like & $\begin{array}{l}\text { Atmospheric pressure } \\
\text { plasma }\end{array}$ & TEGDME (aerosol) & Antibiofilm coating & [47] \\
\hline $\begin{array}{c}\text { Nano } \\
\text { bio-composite }\end{array}$ & DBD planar & $\begin{array}{l}\text { Acetylene (gas) or pyrrole } \\
\text { (vapor, bubbler) }+\mathrm{GO}_{x} \text { or } \\
\text { lipase or allophycocyanin or } \\
\text { alkaline phosphathase in } \\
\text { water (aerosol) }\end{array}$ & Bioactive coating & [48] \\
\hline $\begin{array}{l}\text { Fluorocarbon } \\
\text { coating }\end{array}$ & Pin corona discharge & HDFD (aerosol) & Hydrophobic coating & [49] \\
\hline $\begin{array}{c}\text { Hybrid } \\
\text { organic/inorganic }\end{array}$ & plasma jet & $\begin{array}{c}\mathrm{TiO}_{2} \text { in } \mathrm{TMOS} / \text { alcohol } \\
\text { (aerosol) }\end{array}$ & Anti-wear coatings & {$[50]$} \\
\hline $\begin{array}{c}\text { Hybrid } \\
\text { organic/inorganic }\end{array}$ & $\begin{array}{l}\text { DBD planar, remote } \\
\text { atomization }\end{array}$ & $\begin{array}{c}\text { lanthanide-containing } \\
\text { coordination polymer } \\
\text { particles from the } \\
{\left[\mathrm{Tb}_{2}-\mathrm{xYx}\left(\mathrm{C}_{8} \mathrm{H}_{4} \mathrm{O}_{4}\right)_{3}\left(\mathrm{H}_{2} \mathrm{O}\right)_{4}\right] \mathrm{N}} \\
\text { family in } \mathrm{HMDSO} / \text { ethanol } \\
\text { (aerosol) }\end{array}$ & Luminescent coating & {$[51]$} \\
\hline $\begin{array}{l}\text { Organic coating } \\
\text { PEG-like }\end{array}$ & DBD planar & $\begin{array}{c}\text { Lactic acid or TEGDME } \\
\text { (aerosol) }\end{array}$ & Biodegradable non-fouling & [52] \\
\hline $\begin{array}{c}\text { Nano } \\
\text { bio-composite }\end{array}$ & DBD planar & $\begin{array}{c}\text { Acetominophen } \\
\text { containing/MAA EGDMA }\end{array}$ & Drug delivery & [53] \\
\hline $\begin{array}{l}\text { Organic coating } \\
\text { PEG-like }\end{array}$ & DBD planar & TEGDME (aerosol) & Non-fouling & [54] \\
\hline Organic coating & DBD planar & $\begin{array}{l}\text { Anhydride methacrylic } \\
\text { (aerosol) }\end{array}$ & $\begin{array}{c}\text { Biocompatible and } \\
\text { biodegradable coating }\end{array}$ & [55] \\
\hline Organic coating & DBD planar & $\begin{array}{c}\text { Ethylene (gas) + water } \\
\text { (aerosol) }\end{array}$ & Functional coating & [56] \\
\hline $\begin{array}{c}\text { Hybrid } \\
\text { organic/inorganic }\end{array}$ & DBD planar & $\begin{array}{l}\text { ZnO NPs in n-octane } \\
\text { (aerosol) }\end{array}$ & $\begin{array}{l}\text { Photocatalytic and } \\
\text { self-cleaning }\end{array}$ & [57] \\
\hline PEG-like & DBD planar & PCL diol $(\mathrm{a} / \mathrm{m})$ & $\begin{array}{l}\text { Biodegradable for } \\
\text { biomedical }\end{array}$ & [58] \\
\hline $\begin{array}{c}\text { Nano } \\
\text { bio-composite }\end{array}$ & DBD planar & $\begin{array}{l}\text { Ethylene (gas) + lysozyme in } \\
\text { water (aerosol) }\end{array}$ & Antibacterial coating & [59] \\
\hline $\begin{array}{c}\text { Hybrid } \\
\text { organic/inorganic }\end{array}$ & DBD planar & $\begin{array}{l}\mathrm{TiO}_{2} \mathrm{NP} \text { in HMDSO } \\
\text { (aerosol) }\end{array}$ & $\begin{array}{l}\text { Self-cleaning super } \\
\text { hydrophilic layers. }\end{array}$ & [60] \\
\hline $\begin{array}{c}\text { Hybrid } \\
\text { organic/inorganic }\end{array}$ & DBD planar & $\begin{array}{c}\mathrm{TiO}_{2} \mathrm{NP} \text { in water (aerosol)+ } \\
\text { HMDSO(bubbler) }\end{array}$ & $\begin{array}{l}\text { Self-cleaning super } \\
\text { hydrophilic layers. }\end{array}$ & [61] \\
\hline $\begin{array}{c}\text { Hybrid } \\
\text { organic/inorganic }\end{array}$ & Plasma jet & $\begin{array}{l}\text { acrylic acid (bubbler) }+\mathrm{Ag} \\
\text { NPs in EtOH (aerosol) }\end{array}$ & Antibacterial coating & [62] \\
\hline $\begin{array}{c}\text { Nano } \\
\text { bio-composite }\end{array}$ & DBD planar & $\begin{array}{l}\text { Ethylene (gas) + vancomycin } \\
\text { in water (aerosol) }\end{array}$ & $\begin{array}{l}\text { Free standing antibiotic } \\
\text { coating }\end{array}$ & [63] \\
\hline $\begin{array}{c}\text { Nano } \\
\text { bio-composite }\end{array}$ & DBD planar & $\begin{array}{l}\text { Ethylene (gas) + lysozyme in } \\
\text { water (aerosol) }\end{array}$ & Antibacterial coating & [64] \\
\hline Organic coating & DBD planar & L-DOPA in VTMOS (aerosol) & Binding of nanoparticles & [65] \\
\hline Organic coating & DBD planar & $\begin{array}{l}\text { L-DOPA in Methacrylic acid } \\
\text { (aerosol) }\end{array}$ & Functional coating & [66] \\
\hline Organic coating & Plasma jet & Collagen in water (aerosol) & $\begin{array}{l}\text { Plasma medicine, burn } \\
\text { treatment }\end{array}$ & [67-69] \\
\hline
\end{tabular}


Table 1. Cont.

\begin{tabular}{ccccc}
\hline Coating Category & Reactor Set Up & Feed & Application & Ref. \\
\hline $\begin{array}{c}\text { Nano } \\
\text { bio-composite }\end{array}$ & DBD planar & $\begin{array}{c}\text { Lysozyme in water (aerosol) } \\
\text { + ethylene (gas) }\end{array}$ & Biosensor & {$[70]$} \\
\hline Organic coating & DBD planar & $\begin{array}{c}\text { N,N'-methylenebisacrylamide } \\
\text { (aerosol) }\end{array}$ & $\begin{array}{c}\text { Amine/amide-rich coatings } \\
\text { with good biocompatibility }\end{array}$ & {$[71]$} \\
\hline $\begin{array}{c}\text { Nano } \\
\text { bio-composite }\end{array}$ & DBD planar & $\begin{array}{c}\text { Ethylene (gas) + gentamicin } \\
\text { water (aerosol) }\end{array}$ & Antibacterial coating & {$[72]$} \\
\hline $\begin{array}{c}\text { Nano } \\
\text { bio-composite }\end{array}$ & DBD planar & $\begin{array}{c}\text { Ethylene (gas) + vancomycin } \\
\text { in water (aerosol) }\end{array}$ & $\begin{array}{c}\text { Antibiotic } \\
\text { coating/nanocapsules }\end{array}$ & {$[73-75]$} \\
\hline $\begin{array}{c}\text { Hybrid } \\
\text { organic/inorganic }\end{array}$ & DBD planar & $\begin{array}{c}\text { POSS NPs in HMDSO } \\
\text { (aerosol) }\end{array}$ & $\begin{array}{c}\text { Selective liquid diffusion } \\
\text { membranes }\end{array}$ & {$[76]$} \\
\hline
\end{tabular}

Notwithstanding the electrode assembly and the kind of atomizer considered, we can essentially identify two approaches to inject a feed in the plasma when coupling it with an aerosol, with the aim of depositing a coating. As depicted in Figure 4, they mostly differ in the way in which the main film precursor is admitted, either through the same aerosol or an auxiliary line.

In the first approach (I), either the monomer (Ia), pure or dispersed in a solvent, or the dispersion of an active compound (e.g., a drug) in the monomer (Ib), is atomized in the plasma. In this case, all the building blocks for the coating deposition are introduced through the aerosol; therefore, there is no need for an auxiliary line for the addition of a film precursor.

Approach II consists of the atomization of a solution (or suspension) typically not useful for film formation, hence the main film precursor is injected through an auxiliary line, though, in principle, depending on the operational conditions, it could be a second atomizer. The sentence "not useful for film formation" deserves clarification: the atomization of a solution of a drug or a suspension of nanoparticles in a plasma, even without a coating precursor, can give rise to the growth of a film, mostly due to the adsorption of the components of the mixture, eventually altered by the physical action of the plasma. However, such coatings would be poor-quality ones, with low adhesion and cohesion.

Approach Ia is usually followed to prepare single-component thin films, such as siloxane coatings from organosilicon monomers, as hexamethyldisiloxane (HMDSO) or Tetraorthosylicate (TEOS) [38,40,46], carboxylic group-rich coatings from acrylic acid [33,36,41], Polyethyelene Oxide (PEO)-like coatings from glymes [54] and hydrophobic coatings [77].

The monomer can be supplied pure or dispersed in a solvent. This is particularly relevant if the film precursor is solid, and hence is unable to be atomized at room temperature. Moreover, viscous liquid precursors can be better atomized with the addition of a solvent-in fact, notwithstanding the nature of aerosol generation, viscosity places limitations on the energy transfer necessary for liquid break-up in the droplets and for jet stability [1].

Methods Ib and II are very appealing since they can be used for the synthesis of multicomponents and, in some cases, nanocomposite coatings in one step. The versatility of these methods is straightforward: by changing the monomer and the additive dispersed in the atomizer mixture in Ia, or changing the monomer in the auxiliary line and the additive in the aerosol, it is possible to deposit a wide range of multicomponent coatings. In particular, for $\mathrm{Ib}$, the dispersion of nanoparticles (NPs) in monomers has been reported: $\mathrm{TiO}_{2}$ /organosilicon [50,60], $\mathrm{AlCeO}_{3} / \mathrm{HMDSO} /$ ethanol [45], $\mathrm{ZnO}$ octane [57], polyhedral oligomeric silsesquioxane (POSS)/HMDSO [76]. In case II, a gaseous monomer is often inlet, as ethylene, with an aerosol in an aqueous solution of vancomycin [63,73,74], gentamicin [72] or lysozyme [59]; on the other hand, the monomer can be inlet by means of a bubbling system, as reported for the deposition of Ag NPs containing films [62], or silica layers entrapping $\mathrm{TiO}_{2}$ NPs [61]. 
I

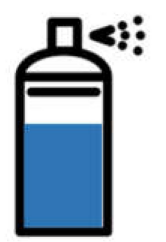

a

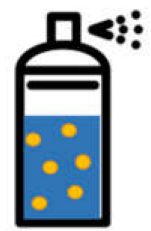

b

\section{Monomer or its solution}

Additive (suspended or dissolved)

Solvent

\section{AUX Monomer (gaseous or as an aerosol)}

Figure 4. Scheme of possible coupling of atomization sources to atmospheric pressure (AP) plasma.

The additive can be a compound soluble in the aerosol liquid feed, but it can consist of both organic (e.g., polymer nanopowder) or inorganic (metals or metal oxides) nanoparticles. In this case, the liquid will be a suspension and it will need continuous stirring during aerosol generation in order to ensure the constant composition homogeneity of the drops. Nevertheless, considering method $\mathrm{Ib}$, though it allows for the atomization of two different building blocks at once with only one atomizer, their relative abundance in the final coating will depend on the composition of the dispersion in the liquid feed. Therefore, this can only be changed by preparing atomizer liquid with different compositions. On the other hand, in method II, the two coating components are supplied through two separated sources, hence their relative abundance in the plasma feed can be continuously tuned by changing the relative flow rate in the aerosol generator and in the auxiliary line. To better clarify this, Yang et al. deposited $\mathrm{OH}$-containing organic coatings in a system, where the atomizer was used to inject water and ethylene was added through the auxiliary line [56]. By changing the relative flow rate ratio of the aerosol carrier gas and of ethylene, they successfully tuned the hydroxyl content in the deposited coating. This particular case uses method II, where the additive is not a dispersion but a pure solvent, and the process does not lead to a composite coating. These differences are summarized in Table 2.

It is also important to discuss the coatings' stability upon immersion in liquid. The stability of the coatings depends on numerous variables, and cannot be correlated to a specific injection mode. Furthermore, the three approaches lead to coatings with completely different characteristics and a comparison can hardly be made. However, as a general view, the coatings deposited by Ia are normally homogeneous and, as such, can more easily resist liquid immersion. On the other hand, methods $\mathrm{Ib}$ and II lead to composite films that often have a complex morphology and, hence, are more easily attacked by solvents. Some more specific issues regarding the coatings' stability will be discussed in the following sections.

The morphology of the deposited coatings plays a crucial role in their application. For most applications, like barrier layers or dielectrics, a smooth surface is necessary, whereas nano- and micro-roughness are desired in other technological fields, such as catalysis or liquid repellent materials. In the case of AAPD, if the atomized feed is not heated before the processing zone, droplets can be present in the plasma phase; then, the interaction between the active species and the feed molecules is weakened, and this can lead to the formation of aggregates. This is a factor that should be considered in the process optimization, when the morphology is relevant. Some works deal with the optimization of smoothness/roughness in AAPD. I.R. Duran et al. studied the effect 
of monomer structure on the morphology of coatings deposited from organosilicon aerosol-fed plasma $[78,79]$. They studied four siloxane precursors, namely 1,3,5,7-tetra-methylcyclotetrasiloxane (TMCTS), octamethylcyclote-trasiloxane (OMCTS), 1,1,3,3-tetramethyldisiloxane (TMDSO), and hexamethyldisiloxane (HMDSO), with the first two studied cyclically. They found a rougher surface with globular features for the former two monomers, which was likely because heavier film precursors with high sticking coefficients were formed in the plasma. J. Profili et al. compared coatings deposited from atomized $\mathrm{HMDSO}$ with and without $\mathrm{TiO}_{2}$ and they found, as expected, a rough surface $\left(R_{\mathrm{rms}}\right.$ in the range 32-60 nm) when NPs where present in the feed, but the morphology was also influenced by source voltage waveforms [60]. V. Jalaber et al. demonstrated that the duty cycle of a pulsed source can be controlled to tune the morphology of catechol-containing films [80].

It should be mentioned that, in some AAPD setups, the atomization is carried out remotely: the aerosol injection occurs outside the electrode zone. Therefore, droplets impinge on the substrate, without passing through the plasma region, as in the system reported in Figure 5. In the kind of system we refer to in this review, the sample is often placed on a movable stage, and passes alternatively from an aerosol injection section to a plasma one, several times. During the injection step, the precursor is simply adsorbed onto the sample surface, but then it moves to the plasma source section, where the adsorbed layer reacts with the impinging active species (such as excited neutrals and photons). These interactions lead to the formation of a film, even if this film is limited in terms of its adhesion to the substrate.

In other examples, typically in plasma jet configuration, the precursor can be injected downstream with respect to the plasma generation region, directly into the expanded plume. In both mentioned cases, the reasons for using this approach are twofold: (i) the reduced interaction of precursor molecules with the plasma, or (ii) the better operating stability and reduced electrode contamination of the plasma source. As a consequence of the former, the structure of the precursor is less altered or not altered at all by the active plasma species and a coating with a higher retention of the monomer structure can be obtained.

In the next section, some relevant examples will be discussed to provide an overview of the possible coating solutions offered by coupling plasma with aerosol feeding systems. The discussion is organized into the following categories:

- Plasma deposition of single-component coatings (method Ia);

- Plasma deposition of composite coatings (methods Ib and II).

We the term "single component" coating to distinguish from the composite ones made of two or more chemically different constituents.

Table 2. Comparison of the different aerosol/plasma couplings.

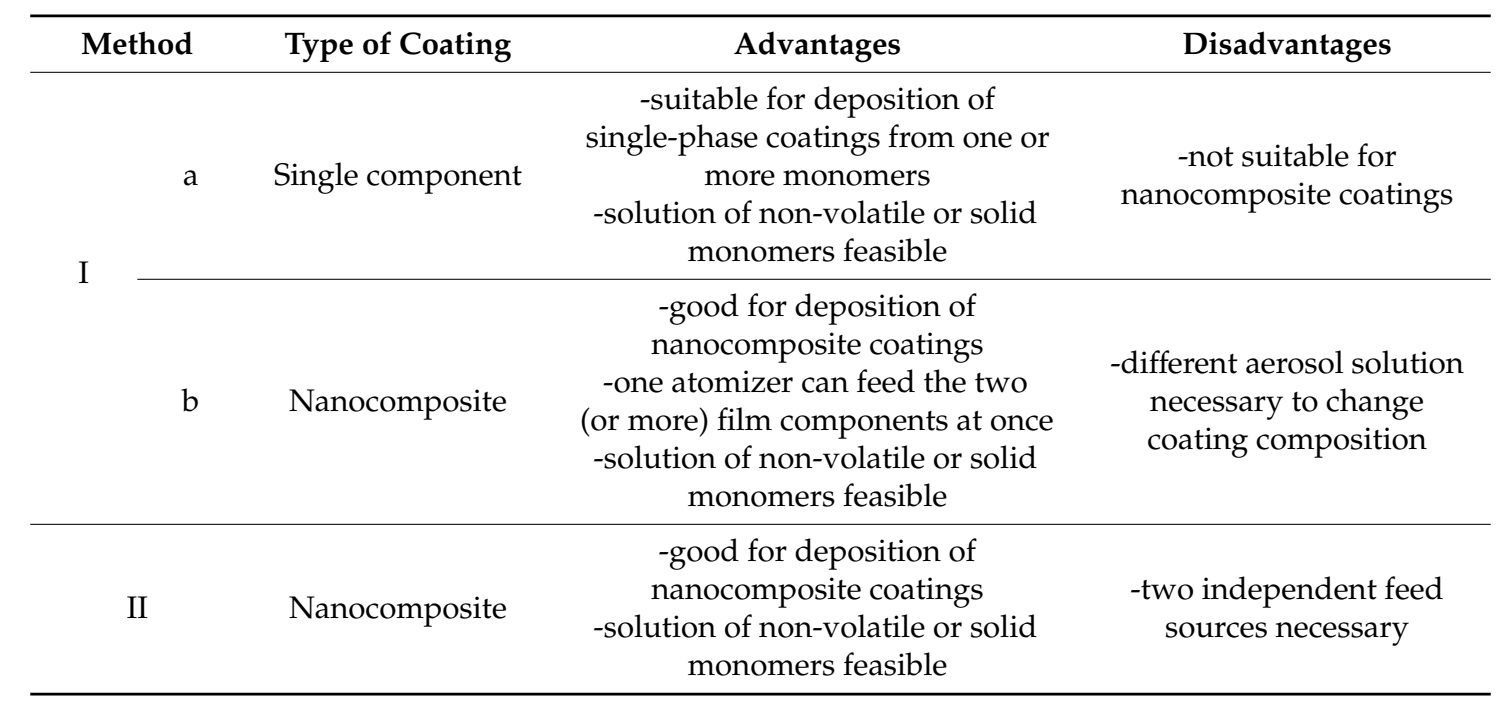




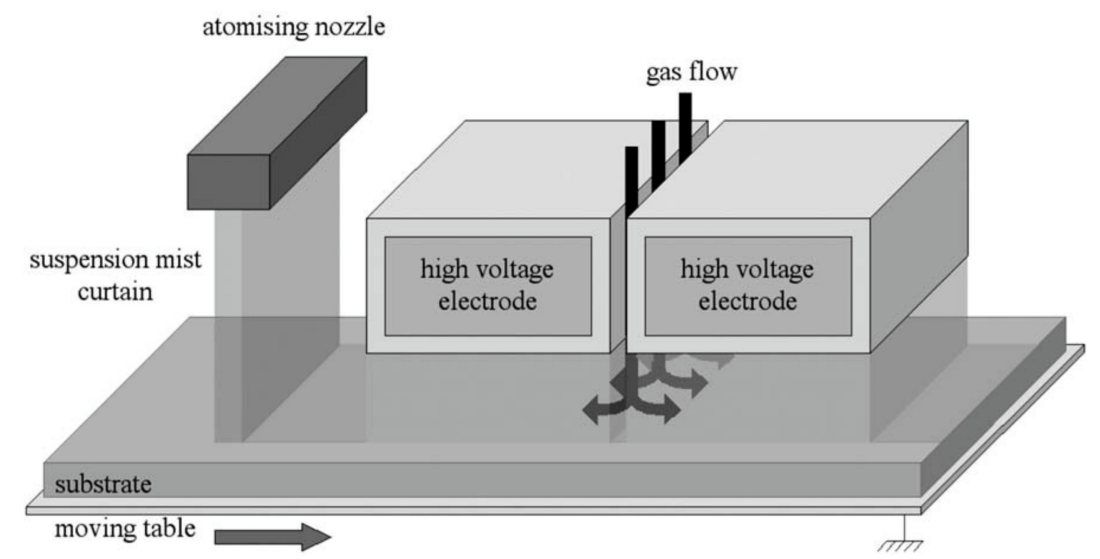

Figure 5. Schematic illustration of the gas-sensing coating deposition from an atomizing nozzle and an AP-DBD. Reprinted with permission from [81]. Copyright 2006 John Wiley \& Sons, Inc.

\section{Aerosol-Assisted Atmospheric Pressure Plasma Deposition}

\subsection{Plasma Deposition of Single-Component Coatings}

An important issue in PE-CVD is to successfully deposit organic coatings from a given precursor, while maintaining their moieties as much as possible. Some examples are PEO-like films, carboxylic group-rich films, or amino-containing coatings. However, especially in vacuum based plasma deposition, it is hard to avoid the severe fragmentation of the precursor, except when some expedient is introduced in the process, often leading to a deposition rate reduction (e.g., working in pulse mode [82]).

Bernard Nisol et al. carried out a comparative experiment in atmospheric pressure argon plasma, feeding the monomer, tetraglyme, using an aerosol (AAPD) or a bubbling system (APPE-CVD), in order to prepare protein-resistant coatings [47]. In both cases, the monomer was introduced remotely with respect to the plasma zone. They observed a better retention of the monomer structure in AAPD, notwithstanding the input power investigated, whereas, in APPE-CVD, the higher fragmentation of the monomer was found, which increased with the power. Furthermore, for the latter, the protein adsorption resistance decreased alongside the process power as a result of the worst PEO-structure, while for the aerosol-based process, there was no detrimental effect on the power, as shown in Figure 6.

Similarly, Da Ponte et al. found that, in the plasma deposition of PEO-like coatings, when the precursor was introduced by atomization, the power had a mild effect on the monomer structure retention, while gas feed dilution was more effective in reducing the ethylene oxide content [52,54].

Another typical organic coating deposited by plasma is one bearing carboxylic groups, especially when these are acidic [41]. Such functionalized films are extremely important as an intermediate step toward the immobilization of active molecules to an "inert" surface, which his relevant in the development of biomaterials and sensors, or to enhance component adhesion in composites. One pioneering work in this regard is that of L.J. Ward et al. [33]: they developed an ultrasonic atomizer, which acted as a ground electrode to a glass dielectric connected to an high volatge supply, as shown in Figure 7. Feeding acrylic acid with helium through the atomizer resulted in the very good retention of acrylic acid groups, with quite a high deposition rate (more than $200 \mathrm{~nm} / \mathrm{min}$ ). 


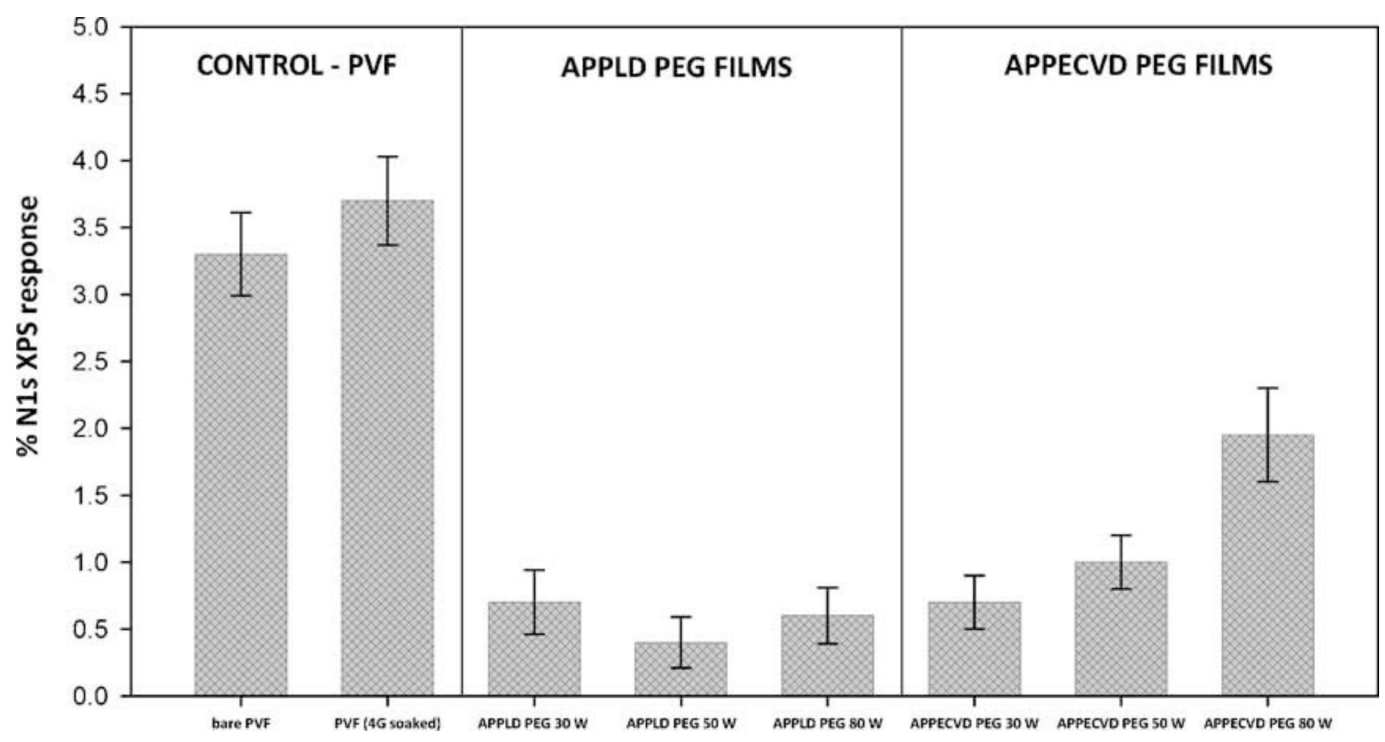

Figure 6. Protein adsorption expressed as X-ray Photoelectron Spectroscopy (XPS) nitrogen atomic percentage of uncoated polyvinylidene fluoride (PVF, control) and coated samples, by aerosol injection (APPLD PEG), or bubbling one (APPE-CVD), after Bovine Serum Albumin (BSA) exposure. Reprinted with permission from [47]. Copyright 2006 John Wiley \& Sons, Inc.

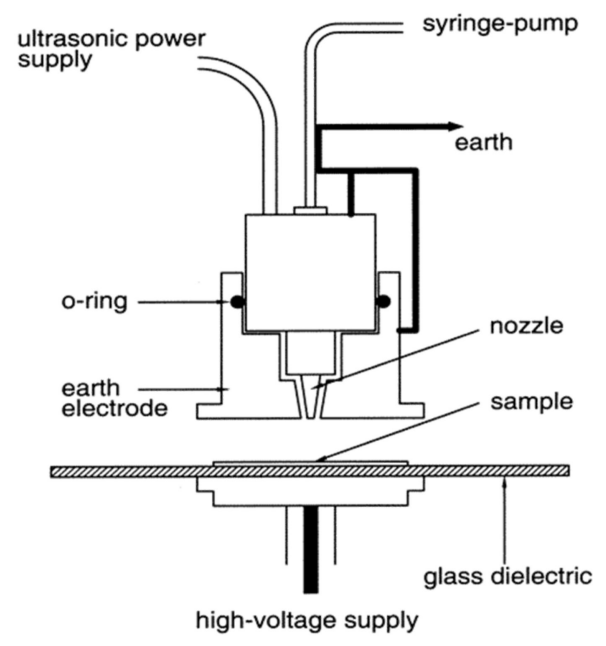

Figure 7. Schematic of AAPD deposition apparatus (approximate height: $30 \mathrm{~cm}$ ). Reprinted with permission from [33]. Copyright 2003 American Chemical Society.

Tatoulian et al. instead nebulized acrylic acid by electro-hydrodynamic atomization (EHDA) [36,83]. A voltage of $6 \mathrm{kV}$ DC is applied at the nozzle, through which the monomer is supplied. In this way, droplets do not coalesce as they are charged and their orientation toward the grounded electrode is favored, along with the deposition rate. This work demonstrated a good retention of carboxylic groups and very good stability in water, which is often a main issue for these kinds of films, which are mainly intended for wet applications.

Often, a main issue of plasma-deposited functionalized organic coatings is their stability in liquid, mostly aqueous media. This is due to the significant polar character of the surface, resulting in a strong interaction with water. In AAPD, this can be a more compelling issue when the precursor arrives in the discharge in the form of droplets, meaning that it is less prone to react with the plasma species. Some papers discuss how to handle this issue. Donegan et al. demonstrated that air-fed plasma jets were more effective at crosslinking acrylic acid-depositing coatings, meaning that they were able to produce 
- $\mathrm{COOH}$-rich films that were stable in water [84]. A similar stabilization can be achieved by the addition of a crosslinker to the acrylic acid aerosol feed, methylene-bis-acrylamide, and its deposition onto a heated substrate [85]. Heating the substrate at $120^{\circ}$ was demonstrated to be a feasible method for the deposition of stable PEO-like coatings from tetraethylene glycol dimethyl ether [86].

Deposition processes from organosilicon and fluorocarbon feeds are amongst the most investigated in plasma surface treatment. Organosilicon-fed plasma with the possible addition of oxygen can be applied in order to prepare dielectrics in microelectronics $[87,88]$, gas and vapor barriers in packaging [89] and protective layers (mostly against metal corrosion) [90].

J. Bour et al. deposited coatings from a semi-dynamic DBD reactor, as illustrated in Figure 8, for the corrosion protection of steel. HMDSO was the atomized monomer, using air as supply gas, and silicone-like coatings were obtained with a metal protective character similar to traditional chromatization methods.

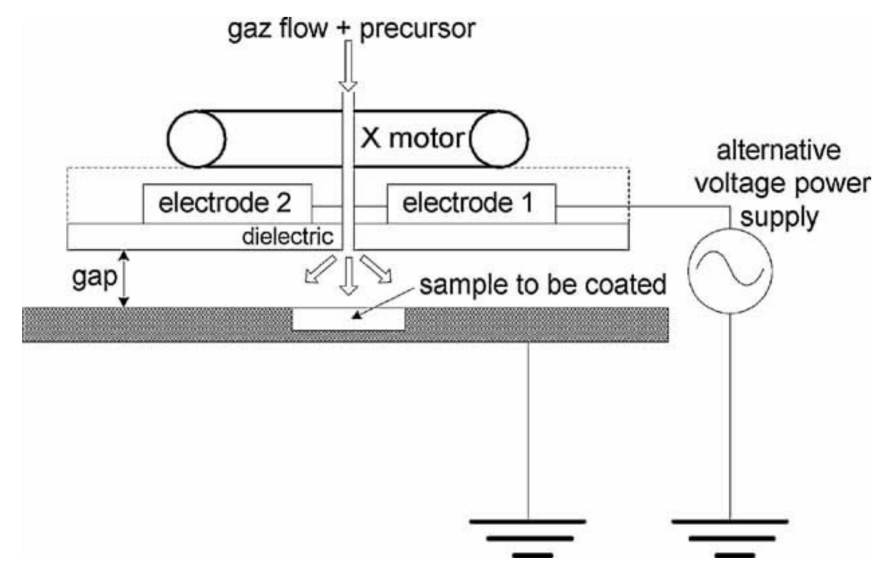

Figure 8. Scheme of the experimental atmospheric DBD plasma deposition reactor for the deposition of organosilicon coatings. Reprinted with permission from [40]. Copyright 2006 John Wiley \& Sons, Inc.

More recently, I.A. Duran et al. exploited the AAPD of organosilicon-based coatings as fog-resistant surfaces $[78,79]$. They proved that coatings deposited from octamethylcyclotetrasiloxane, with the addition of $\mathrm{N}_{2} \mathrm{O}$ as an oxidant (in an amount $50 \%$ greater than stoichiometric), were superhydrophilic and, hence, antifog. Their hydrophilic character was ascribed to the fact that they were rich in $\mathrm{Si}-\mathrm{OH}$ groups, and the coatings remained antifog even after washing, if annealed at $100{ }^{\circ} \mathrm{C}$ for $1 \mathrm{~h}$.

Numerous articles can be found on the plasma deposition of fluorocarbon coatings, mostly for wettability control application, since hydrophobic and, in some cases, water-repellent surfaces can be obtained $[10,91,92]$. Few works concern the AAPD of fluorocarbon films. It should be mentioned that L. O'Neill et al. studied two different liquid monomers, $1 \mathrm{H}, 1 \mathrm{H}, 2 \mathrm{H}, 2 \mathrm{H}$-heptadecafluorodecyl acrylate (HFDA) and 1H,1H,2H-perfluoro-1-decene (HDFD), but they succeeded in producing hydrophobic coatings only with HFDA; HDFD leads to unusable oily films [42,44,49]. The reason was that aerosol droplets can act as electron sinks, hence leading to power dissipation and, in turn, to the scarce activation/fragmentation of the film precursor. This is a general issue when dealing with aerosol-assisted plasma deposition.

Other examples of organic coatings deposited by AAPD are NH-rich from methylenebisacrylamide [71] and polycaprolactone [43,58]; however, further hints can be found in [37], where the plasma deposition from 22 different organic monomers (from alkane to organosilicon and acrylate) were nebulized in a parallel-plate DBD.

M. Garzia Trulli et al. deposited 3-aminopropyltriethoxysilane-based coatings onto porous alumina microparticles [93]. The latter were placed on a 3- $\mu \mathrm{m}$-thick PVDF membrane foil on the bottom ground electrode, in a parallel-plate DBD system, equipped with a vacuum system to hold the powders in place during the plasma treatments and avoiding their removal. Particles were homogeneously 
covered by the coating, and, interestingly, transmission electron microscopy analyses pointed to a penetration of the coating up to $1 \mu \mathrm{m}$ in depth through the nanopores in the alumina particles.

M. Moreno-Couranjou et al. proposed the deposition of cathecol-containing films from an aerosol of N-(3,4-dihydroxyphenyl)acrylamide (DOA) dissolved in vinyltrimethoxysilane (VTMOS), in a reactor similar to the one shown in Figure $5[65,66]$. The nebulization of the precursors was in remote position with respect to the plasma source, and this approach allowed for the deposition of a "co-polymer" of DOA and VTMOS. Hence, following the scheme reported in Figure 9, by two further wet steps, they bound Ag NPs, transforming the catechol groups into quinone ones, then the latter were used to bind dispersine [65] or ranaspumin-2 [66] antifouling enzymes. They proved that the enzymes were effective against Bacillus subtilis in fighting biofilm formation, while the presence of $\mathrm{Ag}$ NPs provided a coating with an antibacterial effect.

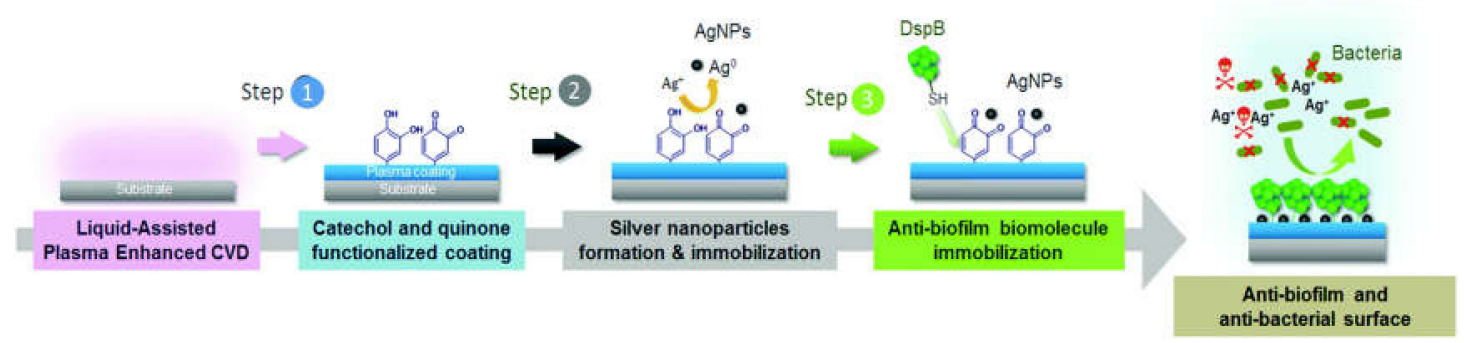

Figure 9. Schematic illustration of the elaboration of multifunctional surfaces achieved via aerosol-assisted PE-CVD of a catechol-quinone functionalized coating for co-immobilizing Ag NPs and biomolecules. Reprinted with permission from [65]. Copyright 20018 Royal Society of Chemistry.

We can close this section with an example illustrating one main advantage of aerosol/plasma coupling: the possibility of depositing biomolecules. L. O'Neill et al. proposed the nebulization of a collagen solution in a plasma jet, as schematized in Figure 10, to coat chronic wounds $[67,68]$. In fact, a crosslinked collagen coating can be deposited and the application of such a plasma jet onto wounds in an immunocompromised rabbit wound model showed no improper effects on animals. The combination of plasma and collagen aerosol produced wound healing that was statistically enhanced over both the control and the plasma treatment groups. Furthermore, the authors have shown that the plasma-deposited plates performed as traditional collagen surfaces in terms of cell viability, proliferation and activity [66].

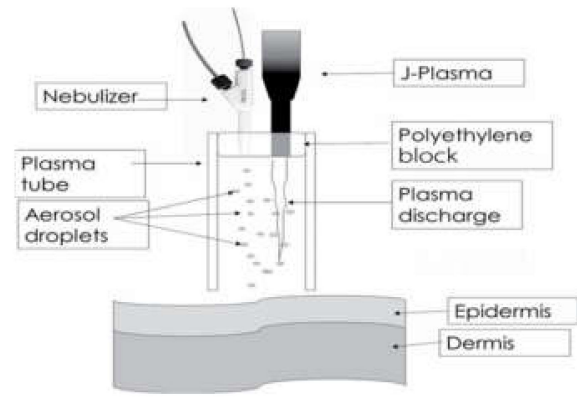

(a)

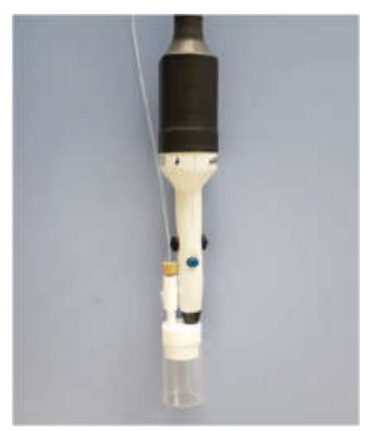

(b)

Figure 10. (a) schematic of plasma chamber with integrated nebulizer designed to fit onto a plasma jet, and, (b) corresponding picture of the device. Reprinted with permission from [68]. Copyright 2018 Begell House, Inc. 


\subsection{Plasma Deposition of Composite Coatings}

A specific characteristic of AAPD, with respect to conventional PE-CVD processes, is the possibility of depositing a nanocomposite (NC) coating in one step. In fact, as mentioned in the previous section, the "filler" can be sprayed onto the plasma via atomization and the matrix precursor can be its solvent, or it can be added by an auxiliary line. It should be highlighted that, as will be clear at the end of this section, there is almost no limit to the choice of the two (or more) components of the composite coating.

Increasingly specific technological needs can be satisfied by combining different materials to produce novel materials and devices with final properties that can be suitably tailored to satisfy the requirements. Polymer NCs consist of a polymer matrix with a large range of filler materials, organic or inorganic, with at least one nanometric dimension. One class of NCs is the organic-inorganic hybrid one, where the filler is comprised of inorganic nanoparticles such as metals (e.g., $\mathrm{Ag}$, $\mathrm{Fe}$, and $\mathrm{Au}$ ) or oxides (e.g., $\mathrm{SiO}_{2}, \mathrm{ZnO}, \mathrm{Al}_{2} \mathrm{O}_{3}, \mathrm{CaCO}_{3}$, and $\mathrm{TiO}_{2}$ ). Depending on the nanoparticles, different properties are ascribed to materials: mechanical, optical, photocatalytic, electrical, and thermal [94-101].

Most of the reported works about the aerosol-assisted deposition of inorganic coatings concern the plasma deposition of $\mathrm{TiO}_{2}$-containing films. A. Dembele et al. proposed the deposition of $\mathrm{TiO}_{2}$ nanoparticles embedded in silica-like films by feeding the DBD plasma with an aerosol comprised of a $\mathrm{TiO}_{2} /$ organosilicon/alcohol mixture, and by using $\mathrm{He} / \mathrm{O}_{2}$ as a discharge gas [50]. The organosilicon was tetramethylorthosilicate and they tested three different alcohols: methanol, octanol and pentanol. More homogeneous coatings were obtained with the latter two alcohols, likely because of the fast evaporation of methanol during the atomization and deposition, leading to nanoparticle aggregation. Moreover, J. Profili et al. deeply investigated the plasma deposition of $\mathrm{TiO}_{2}$-containing silica films in aerosol-coupled DBD processes [60,61]. In [61], they alternated the plasma deposition of a silica layer and the nebulization of titania nanoparticles from an aqueous suspension, but aerosol line was heated to avoid the presence of droplets. Through an auxiliary line, they introduced the precursor for the silica matrix, hexamethyldisiloxane (HMDSO)/ $\mathrm{N}_{2} \mathrm{O} / \mathrm{N}_{2}$. They obtained sandwiched composite coatings with micrometric and sub-micrometric aggregates, as shown in Figure 11. The same authors, in another work, showed that when an HMDSO/ethanol suspension of $\mathrm{TiO}_{2}$ is atomized in a $\mathrm{N}_{2} / \mathrm{N}_{2} \mathrm{O}$ DBD in one step, coatings can be obtained, consisting in aggregate of nanoparticles surrounded by shells of silica [60]. In a similar way, the deposition onto the wood of $\mathrm{ZnO}$ nanocomposite coatings was investigated for their possible application as UV-protecting layers [102]. Composite coatings were prepared by atomizing a suspension of $\mathrm{ZnO}$ nanoparticles ( $3 \mathrm{wt} \%$ ) in HMDSO or pentane in a DBD reactor; in both cases, the oxide nanoparticles were embedded in the coating.

Fanelli et al. studied, in detail, the deposition of hierarchical NC coatings obtained by embedding $\mathrm{ZnO}$ nanoparticles in a hydrocarbon matrix, for their application as catalytic and self-cleaning films $[57,103,104]$. In an He DBD reactor, they atomized a suspension of oleate-capped ZnO NPs $(0.5-5 \mathrm{wt} \%)$ in octane and coatings containing quasi-spherical NP agglomerates were produced, which gave rise to hierarchical surface roughness. Due to this roughness and to the hydrophobic hydrocarbon uppermost layer, a water advancing contact angle as high as $170^{\circ}$ and very low hysteresis were obtained, indicating hydro-repellent behaviour, as illustrated in Figure 12. Furthermore, in a parallel work, the same authors demonstrated that the coatings retained the photocatalytic properties of the ZnO NPs [103]. 


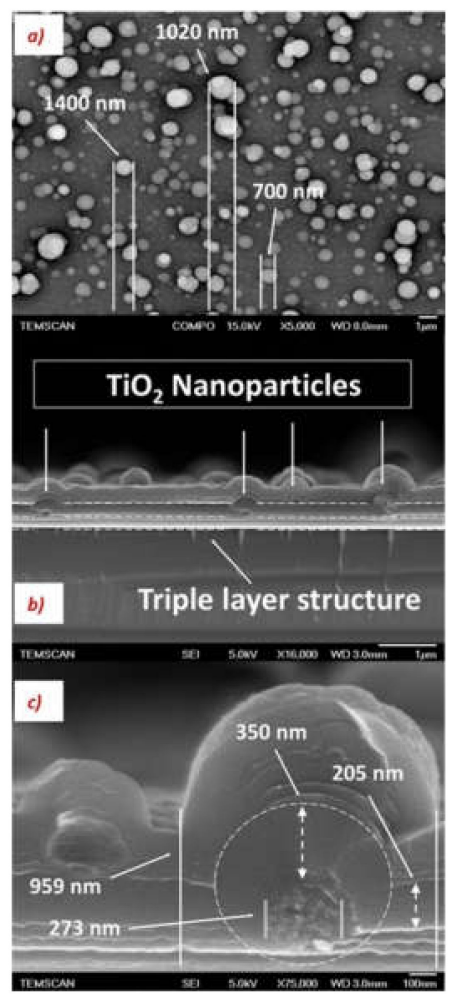

Figure 11. Scanning electron microscopy (SEM) images of the coating, showing heterostructures of $\mathrm{TiO}_{2}$ nanoparticles embedded between thin silica layers. (a) Backscattered image of the top surface, $(\mathbf{b}, \mathbf{c})$ secondary electron images of a cross-section of the coating. Reprinted with permission from [61]. Copyright 2006 John Wiley \& Sons, Inc.
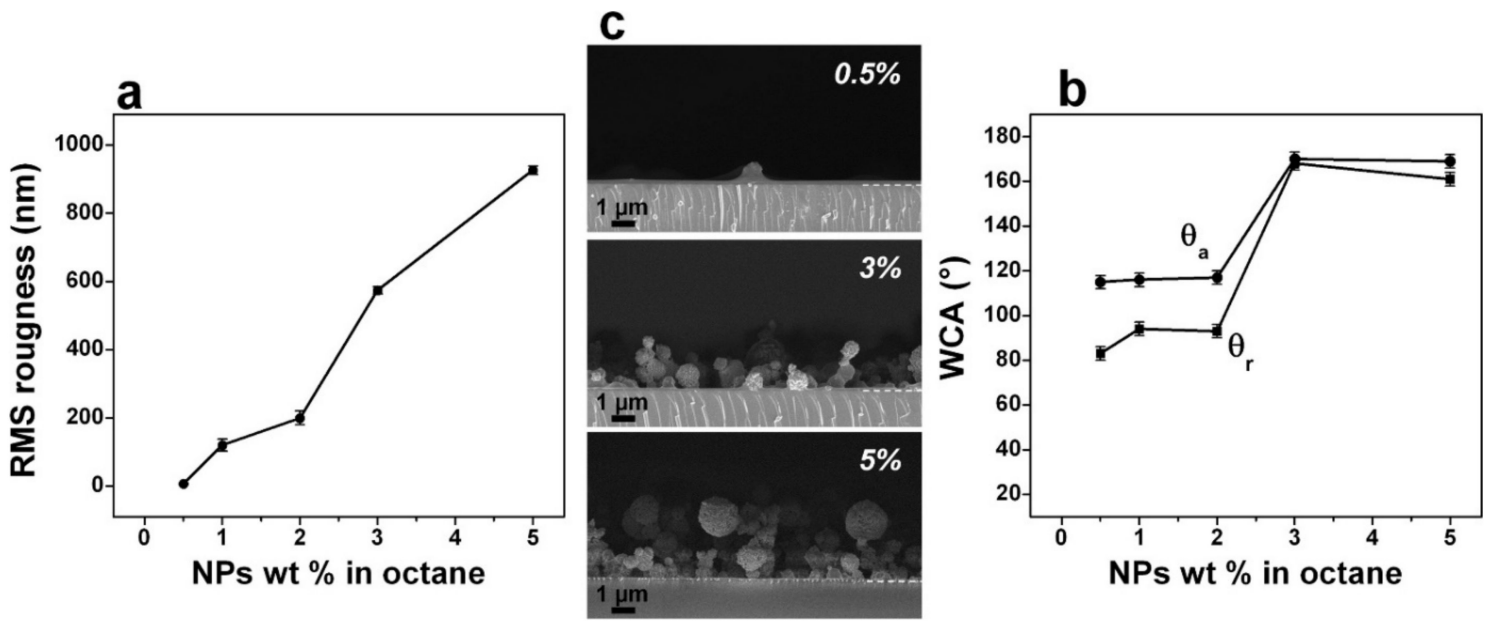

Figure 12. (a) RMS roughness of the nanocomposite coatings as a function of the concentration of oleate-capped $\mathrm{ZnO}$ NPs in the aerosol suspension. (b) Corresponding advancing and receding water contact angle (WCA) for 10 min deposition time. (c) Cross-sectional SEM images of nanocomposite (NC) films deposited from dispersions at different concentration of the oleate-capped ZnO NPs in n-octane $(0.5,3$, and $5 \mathrm{wt} \%)$. Reprinted with permission from [57]. Copyright 2014 American Chemical Society.

One particularly interesting case highlighting the versatility of AAPD composite coatings is that of lanthanide-based hybrid coatings. N.D. Boscher et al. demonstrated the deposition of such coatings when a mixture of $\left[\mathrm{Tb}_{2-x} \mathrm{Y}_{x}\left(\mathrm{C}_{8} \mathrm{H}_{4} \mathrm{O}_{4}\right)_{3}\left(\mathrm{H}_{2} \mathrm{O}\right)_{4}\right]_{\infty}, \mathrm{HMDSO}$ and ethanol was sprayed onto the surface of aluminium or polypropylene foil in the reactor, as illustrated in Figure 5 [51]. Essentially, samples are 
placed on a moving stage and moved forward and backward, relative to the plasma source. Samples pass under the aerosol station and are nebulized with the dispersion and then undergo reaction in the plasma. Samples emit green light by luminescence under UV radiation. Using a similar approach, the same authors successfully obtained well-dispersed NC coatings containing metalloporphyrins from HMDSO/ethanol or HMDSO/chloroform atomizer suspensions [82].

Finally, Anna Liguori et al. deposited a polyacrylic acid matrix containing Ag NP [62]. They fed an Ar plasma jet (Figure 13) with acrylic acid from a bubbling system and ethanol dispersed the Ag NPs $(5 \mathrm{wt} \%$, average NP diameter $100 \mathrm{~nm}$ ). The composite coatings presented a homogeneous distribution of NP aggregates, with dimensions in the range $0.1-1 \mu \mathrm{m}$. When tested against $E$. coli, the Ag NC coatings displayed antibacterial activity.

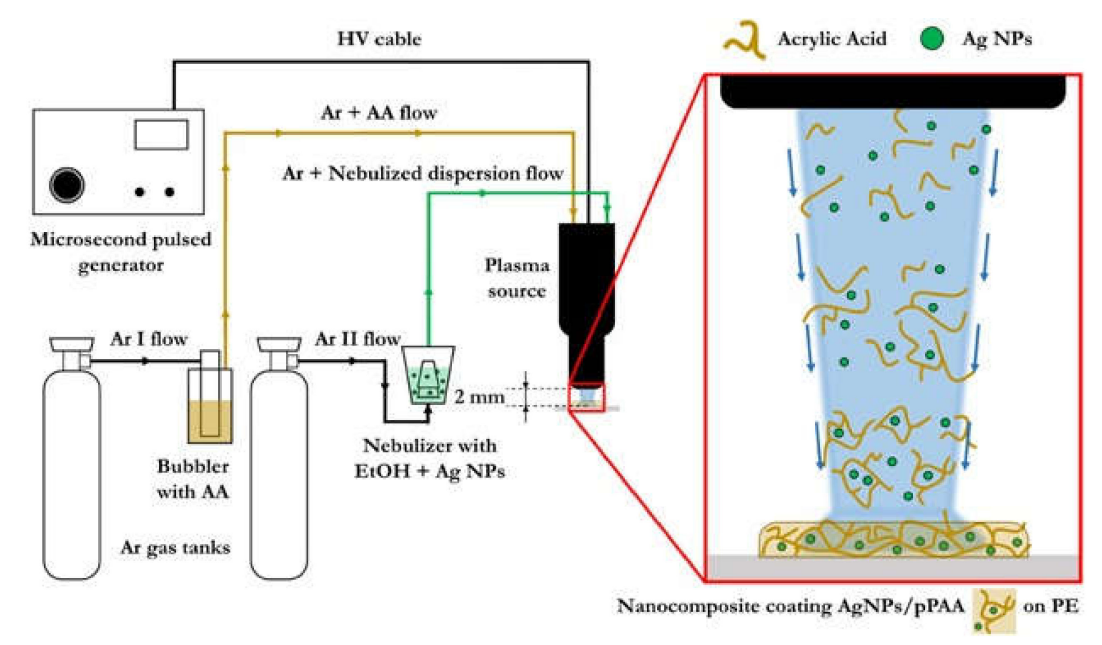

Figure 13. Experimental setup of the plasma co-deposition process of Ag NPs containing organic coatings. Reprinted with permission from [62]. Copyright 2006 John Wiley \& Sons, Inc.

In organic bio-composite coatings, a polymer matrix embeds bioactive components such as proteins, nucleic acids, lipids, drugs, biopolymers or even cells or viruses. Such coatings can find applications in different fields, including biosensing, to exploit the specific interaction of the "filler" with the analyte; as antibacterial or non-fouling films, inhibiting the formation of biofilm by coupling suitable peptides or enzymes; in drug release and, in general, in the biomedical field [105-112].

The possibility of handling such complex and often sensitive molecules, while keeping their bioactivity in such a harsh environment as plasma, is quite intriguing. Aerosol-assisted plasma processing offers this possibility, as will be demonstrated in the following examples, likely due to the shielding role of the solvent, forming a shell around the active molecules and acting as a barrier to the energetic species present in the plasma.

L.A. O'Hare et al. deposited composite coatings containing different antibiotics, cetalkonium chloride, benzalkonium chloride and cetylpyridinium chloride [35]. The active molecule was dissolved in acrylic acid, PEG or their mixture, and atomized in an APP pilot line, as illustrated in Figure 14,

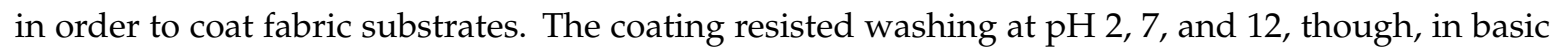
solution, ammonium salts were converted to amine. Microbial tests demonstrated that cetylpyridinium chloride and benzalkonium chloride-containing coatings provide significant protection against the fungal contamination of fabrics. 


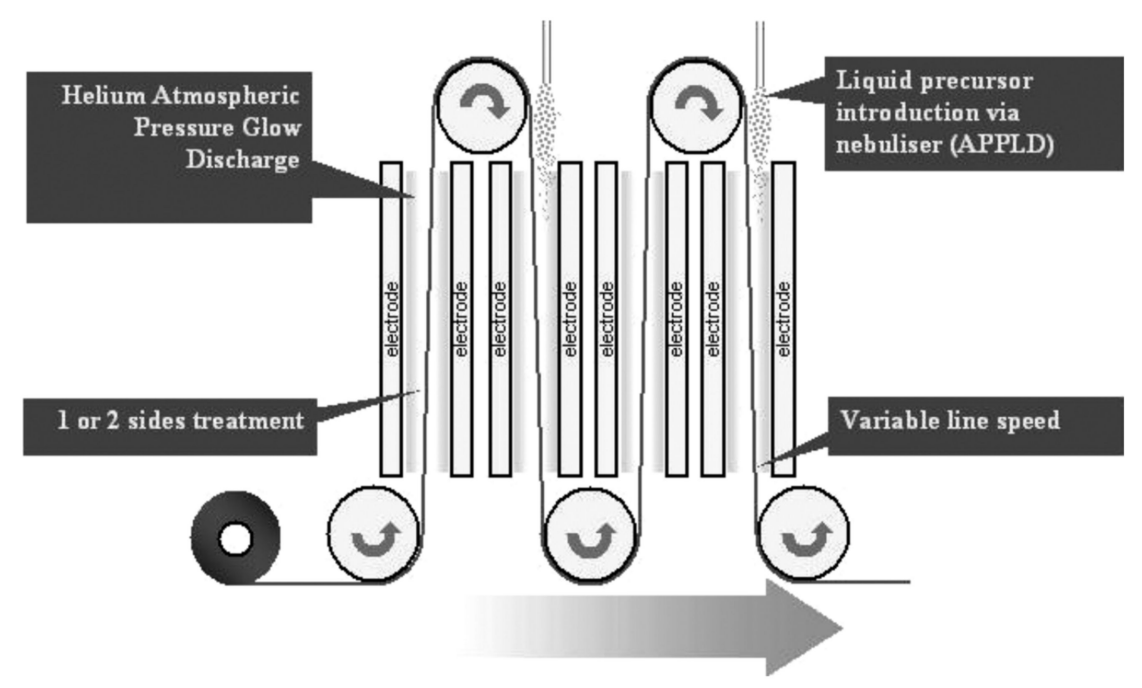

Figure 14. Schematic representation of the roll-to-roll APP reactor for the deposition of composite antibacterial coatings. Reprinted with permission from [35]. Copyright 2006 John Wiley \& Sons, Inc.

The setup schematized in Figure 14 is useful to highlight the feasibility of the upscaling of AAPD processes. In a static configuration, in typical laboratory systems, the plasma deposition from atomized feeds can be inhomogeneous in samples larger than few centimetres; therefore, one could erroneously assume that aerosol coupling to large-scale systems might be an issue. In fact, the configuration illustrated in Figure 14 clearly shows that the use of a suitable system of sample displacement, and the application of injection arrays, can overcome homogeneity problems.

The nebulization of biomolecules (proteins, in particular) in DBD sources, with no activity loss, was demonstrated for the first time by Heyse et al. [48,113], who demonstrated the plasma deposition of active acetylene and pyrrole coatings embedding allophycocyanin, a fluorescent protein, and several enzymes, such as glucose oxidase $\left(\mathrm{GO}_{x}\right)$, lipase and alkaline phosphatase.

F. Palumbo et al. instead worked on the plasma deposition of lysozyme-containing coatings based on a hydrocarbon matrix [59]. Infrared spectroscopy and XPS analysis identified the presence of peptide bonds; however, more interestingly, Matrix-Assisted Laser Desorption/Ionization analyses recognized the presence of a native lysozyme, though part of the most susceptible aminoacidic residues (methionine and tryptophan) presented some oxidation High Performance Liquid Chromatography analysis carried out in water-releasing solution confirmed the presence of a lysozyme $\left(14 \mu \mathrm{g} / \mathrm{cm}^{2}\right)$, while an agar diffusion test demonstrated antibacterial activity close to that of the native enzyme. The conclusion was that plasma exposure did not alter lysozyme structure to such an extent that the antibacterial activity was modified.

In a very similar system, Hsiao et al. replicated these experiments with lysozymes at different distances from the inlet [64]. In contrast to the previous work, they found that spherical structures are formed depending on the position of the samples in the reactor. Similar results were found by Y.-H. Liu et al. for lysozyme and BSA-containing films [70]. Here, an interesting chapter of the story is revealed, and a more detailed discussion can be found elsewhere [114], regarding the formation-in certain cases-of such spherical structures when a solution is atomized in atmospheric pressure plasma. In fact, besides the mentioned papers on lysozymes and BSA, spherical nanostructures were found for vancomycin and gentamicin nanocomposite coatings [63,72-75] during studies on the deposition of antibiotic delivery systems. On the one hand, these papers show that the drugs retain their antibacterial activity once embedded in a plasma polymerized film and gradually released in the aqueous medium. On the other hand, as can be observed in Figure 15, the SEM investigation revealed a unique morphology. Spherical features appeared on the surface, their sizes depending on the experimental conditions. They are larger and more homogeneous in size when running the plasma 
deposition in continuous mode (Figure 15a), while taller aggregates of slightly smaller spheres appear when plasma is pulsed (Figure 15b). More interestingly, after water immersion for $1 \mathrm{~h}$, the spherical features become empty or collapse (Figure 15c). For this reason, but also thanks to further observation by confocal fluorescence microscopy [73], and a more systematic investigation carried out on aerosol solutions fed with compounds possessing different chemical properties [75], it was demonstrated that the spheres had a nanocapsule structure. Such nanocapsules consist of a core made of the solute of the nebulized droplets and a shell formed by the precursor added in the feed-in this case, ethylene. As illustrated in the scheme in Figure 16, the atomized droplets enter the plasma zone, becoming negatively charged (as is well known in the plasma processing scenario, since electrons run over them [11]) and fragments of the matrix precursor surround them. Water evaporation occurs at a constant rate, and aggregates start to form. Polymer deposition starts on the solid aggregates, thus creating the nanocapsules, which then lean on the substrate surface. The formation of the nanocapsules is easier for heavier solid solutes, because of their lower diffusivity and the fact that they possess an ionic character, which is likely because of the presence of a negative charge on the surface of the droplets.

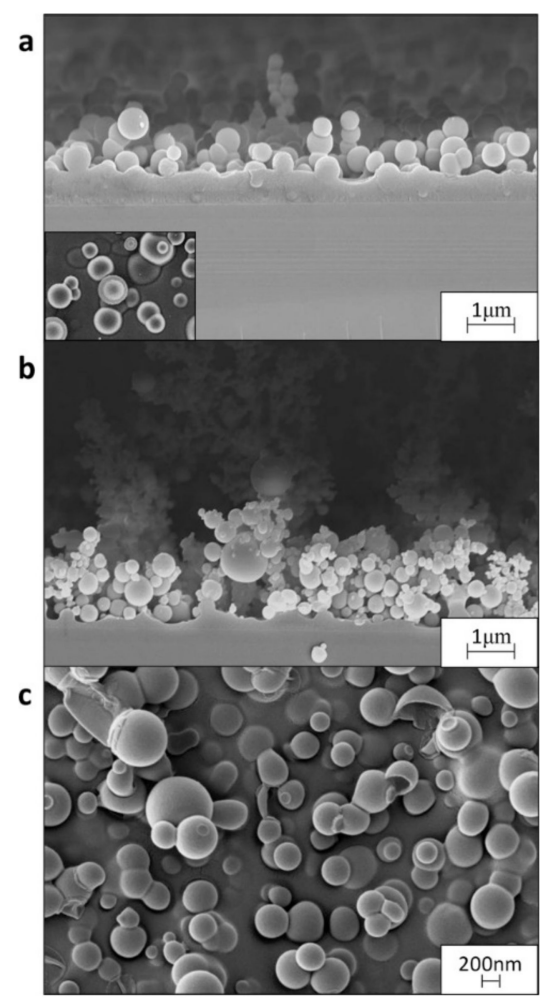

Figure 15. Cross-sectional SEM images of plasma-deposited coatings $(20 \mathrm{sccm}$ ethylene, $5 \mathrm{slm} \mathrm{He}$, $15 \mathrm{mg} / \mathrm{ml}$ of vancomycin solution) in (a) continuous mode (CM, inset top view) and (b) pulse mode condition. (c) Top view: SEM image of a CM plasma-deposited coating after 60 min immersion in water. Reprinted with permission from [74]. Copyright 2006 John Wiley \& Sons, Inc. 


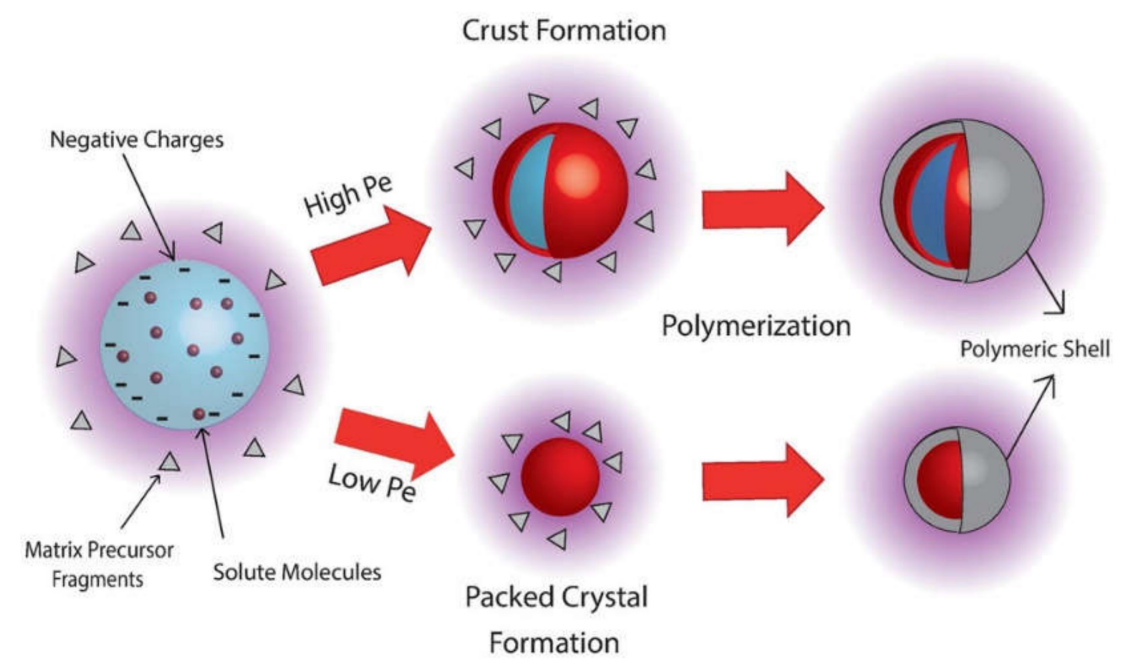

Figure 16. Scheme of the mechanism of nanocapsule formation in aerosol-assisted atmospheric pressure plasma. $P_{e}=K / D$, where $D$ is the mass diffusivity of the particle/solute dispersed in the solvent, and $K$ is the evaporation rate (supposed constant). Reprinted with permission from [75]. Copyright 2006 John Wiley \& Sons, Inc.

\section{Conclusions}

This review provides an up-to-date survey of the current research activities on film deposition by aerosol-assisted atmospheric pressure plasma. The main approaches are reported and discussed, concerning their advantages and drawbacks. Combining precursor atomization to atmospheric pressure plasma largely extends the range of applications of plasma deposition. Some of these applications include:

- Macromolecular compounds, such as biomolecules, can be added to the plasma feed;

- Labile drugs can be embedded in a composite coating;

- Some studies indicate some interesting advantages of atomizing active agents in the presence of plasma for wound healing, and similar applications.

In principle, viruses, bacteria and other cells could be interestingly atomized, even though, to the best of the authors' knowledge, no paper has thus far documented this possibility.

Author Contributions: F.P., Conceptualization, Writing-Review \& Editing; C.L.P., Data Curation, Writing-Review \& Editing; F.F., Funding Acquisition; P.F., Supervision. All authors have read and agreed to the published version of the manuscript.

Funding: This research was partly funded by Regione Puglia "Apulian Industrial Plasma Laboratory, LIPP" and the Italian Ministry for Education (MIUR) under grant PONa3_00369 SISTEMA

Conflicts of Interest: The authors declare no conflict of interest.

\section{References}

1. Kulkarni, P.; Baron, P.A.; Willeke, K. Aerosol Measurement: Principles, Techniques, and Applications, 3rd ed.; John Wiley \& Sons: Hoboken, NJ, USA, 2011; ISBN 9780470387412.

2. Stancampiano, A.; Gallingani, T.; Gherardi, M.; Machala, Z.; Maguire, P.; Colombo, V.; Pouvesle, J.M.; Robert, E. Plasma and aerosols: Challenges, opportunities and perspectives. Appl. Sci. 2019, 9, 3861. [CrossRef]

3. Bhattarai, C.; Samburova, V.; Sengupta, D.; Iaukea-Lum, M.; Watts, A.C.; Moosmüller, H.; Khlystov, A.Y. Physical and chemical characterization of aerosol in fresh and aged emissions from open combustion of biomass fuels. Aerosol Sci. Technol. 2018, 52, 1266-1282. [CrossRef]

4. Vehring, R.; Foss, W.R.; Lechuga-Ballesteros, D. Particle formation in spray drying. J. Aerosol Sci. 2007, 38, 728-746. [CrossRef] 
5. Marchand, P.; Hassan, I.A.; Parkin, I.P.; Carmalt, C.J. Aerosol-assisted delivery of precursors for chemical vapour deposition: Expanding the scope of CVD for materials fabrication. Dalton Trans. 2013, 42, 9406-9422. [CrossRef]

6. Palgrave, R.G.; Parkin, I.P. Aerosol assisted chemical vapor deposition using nanoparticle precursors: A route to nanocomposite thin films. J. Am. Chem. Soc. 2006, 128, 1587-1597. [CrossRef]

7. Hou, X.; Choy, K.L. Processing and applications of aerosol-assisted chemical vapor deposition. Chem. Vap. Depos. 2006, 12, 583-596. [CrossRef]

8. Hou, X.; Choy, K.L. Deposition mechanism and structural characterization of $\mathrm{TiO} 2$ films produced using ESAVD method. Surf. Coat. Technol. 2004, 180, 15-19. [CrossRef]

9. Hou, X.; Choy, K.L. Crystal growth of ZnS films by a charged aerosol-assisted vapor deposition process. Chem. Vap. Depos. 2006, 12, 631-636. [CrossRef]

10. Plasma Deposition, Treatment, and Etching of Polymers; D'Agostino, R. (Ed.) Academic Press: San Diego, CA, USA, 1990; ISBN 9780122004308.

11. Chapman, B. Glow Discharge Processes Sputtering and Plasma Etching; John Wiley \& Sons: New York, NY, USA, 1980.

12. Li, J.; Liu, K.; Yan, S.; Li, Y.; Han, D. Application of thermal plasma technology for the treatment of solid wastes in China: An overview. Waste Manag. 2016, 58, 260-269. [CrossRef]

13. Weltmann, K.D.; Kolb, J.F.; Holub, M.; Uhrlandt, D.; Šimek, M.; Ostrikov, K.; Hamaguchi, S.; Cvelbar, U.; Černák, M.; Locke, B.; et al. The future for plasma science and technology. Plasma Process. Polym. 2019, 16, 1800118. [CrossRef]

14. Fernández-Blázquez, J.P.; Setzer, S.; Del Campo, A. Nanostructured polymer fibers with enhanced adhesion to epoxy matrices. Plasma Process. Polym. 2013, 10, 207-212. [CrossRef]

15. Chatelier, R.C.; Xie, X.; Gengenbach, T.R.; Griesser, H.J. Quantitative Analysis of Polymer Surface Restructuring. Langmuir 1995, 11, 2576-2584. [CrossRef]

16. Balazs, D.J.; Hollenstein, C.; Mathieu, H.J. Fluoropolymer coating of medical grade poly(vinyl chloride) by plasma-enhanced chemical vapor deposition techniques. Plasma Process. Polym. 2005, 2, 104-111. [CrossRef]

17. Coclite, A.M.; Milella, A.; d'Agostino, R.; Palumbo, F. On the relationship between the structure and the barrier performance of plasma deposited silicon dioxide-like films. Surf. Coat. Technol. 2010, 204, 4012-4017. [CrossRef]

18. Achard, J.; Tallaire, A.; Sussmann, R.; Silva, F.; Gicquel, A. The control of growth parameters in the synthesis of high-quality single crystalline diamond by CVD. J. Cryst. Growth 2005, 284, 396-405. [CrossRef]

19. Trizio, I.; Garzia Trulli, M.; Lo Porto, C.; Pignatelli, D.; Camporeale, G.; Palumbo, F.; Sardella, E.; Gristina, R.; Favia, P. Plasma Processes for Life Sciences. In Reference Module in Chemistry, Molecular Sciences and Chemical Engineering; Elsevier Inc.: Waltham, MA, USA, 2018; pp. 1-24.

20. Su, X.; Wu, Y.; Zhang, P.; Xin, Q.; Wang, B. Development of atmospheric pressure plasma processing machine tool for large aperture optics. In Proceedings of the 8th International Symposium on Advanced Optical Manufacturing and Testing Technologies: Advanced Optical Manufacturing Technologies, Suzhou, China, 26-29 April 2016.

21. Fang, Z.; Ding, Z.; Shao, T.; Zhang, C. Hydrophobic surface modification of epoxy resin using an atmospheric pressure plasma jet array. IEEE Trans. Dielectr. Electr. Insul. 2016, 23, 2288-2293. [CrossRef]

22. Penkov, O.V.; Lee, D.H.; Kim, H.; Kim, D.E. Frictional behavior of atmospheric plasma jet deposited carbon-ZnO composite coatings. Compos. Sci. Technol. 2013, 77, 60-66. [CrossRef]

23. Massines, F.; Sarra-Bournet, C.; Fanelli, F.; Naudé, N.; Gherardi, N. Atmospheric pressure low temperature direct plasma technology: Status and challenges for thin film deposition. Plasma Process. Polym. 2012, 9 , 1041-1073. [CrossRef]

24. Armenise, V.; Fanelli, F.; Fracassi, F. Atmospheric pressure plasma treatment of polyurethane foams for heavy metals removal from water. In Proceedings of the 2016 IEEE Nanotechnology Materials and Devices Conference (NMDC), Toulouse, France, 9-12 October 2016.

25. Bosso, P.; Fanelli, F.; Fracassi, F. Deposition of Water-Stable Coatings Containing Carboxylic Acid Groups by Atmospheric Pressure Cold Plasma Jet. Plasma Process. Polym. 2016, 13, 217-226. [CrossRef]

26. Bazinette, R.; Lelièvre, J.F.; Gaudy, L.; Massines, F. Influence of the Discharge Mode on the Optical and Passivation Properties of SiNx:H Deposited by PECVD at Atmospheric Pressure. Energy Procedia 2016, 92, 309-316. [CrossRef] 
27. Reuter, R.; Gherardi, N.; Benedikt, J. Effect of N 2 dielectric barrier discharge treatment on the composition of very thin $\mathrm{SiO}$ 2-like films deposited from hexamethyldisiloxane at atmospheric pressure. Appl. Phys. Lett. 2012, 101, 194104. [CrossRef]

28. Li, D.; Li, N.; Su, X.; Liu, K.; Ji, P.; Wang, B. Characterization of fused silica surface topography in capacitively coupled atmospheric pressure plasma processing. Appl. Surf. Sci. 2019, 489, 648-657. [CrossRef]

29. Li, Z.; Li, Y.; Cao, P.; Zhao, H. Surface Decontamination of Chemical Agent Surrogates Using an Atmospheric Pressure Air Flow Plasma Jet. Plasma Sci. Technol. 2013, 15, 696. [CrossRef]

30. Machala, Z.; Graves, D.B. Frugal Biotech Applications of Low-Temperature Plasma. Trends Biotechnol. 2018, 36, 579-581. [CrossRef]

31. Wang, H.B.; Gao, J.F.; Peng, D.K.; Meng, G.Y. Plasma deposition of La0.8Sr0.2MnO3 thin films on yttria-stabilized zirconia from aerosol precursor. Mater. Chem. Phys. 2001, 72, 297-300. [CrossRef]

32. Soukup, L.; Hubička, Z.; Churpita, A.; Čada, M.; Pokorný, P.; Zemek, J.; Jurek, K.; Jastrabík, L. Investigation of the atmospheric RF torch-barrier plasma jet for deposition of CeOx thin films. Surf. Coat. Technol. 2003, 169, 571-574. [CrossRef]

33. Ward, L.J.; Schofield, W.C.E.; Badyal, J.P.S.; Goodwin, A.J.; Merlin, P.J. Atmospheric pressure plasma deposition of structurally well-defined polyacrylic acid films. Chem. Mater. 2003, 15, 1466-1469. [CrossRef]

34. Vangeneugden, D.; Paulussen, S.; Goossens, O.; Rego, R.; Rose, K. Aerosol-assisted plasma deposition of barrier coatings using organic-inorganic sol-gel precursor systems. Chem. Vap. Depos. 2005, 11, 491-496. [CrossRef]

35. O'Hare, L.A.; O'Neill, L.; Goodwin, A.J. Anti-microbial coatings by agent entrapment in coatings deposited via atmospheric pressure plasma liquid deposition. Surf. Interface Anal. 2006, 38, 1519-1524. [CrossRef]

36. Tatoulian, M.; Arefi-Khonsari, F.; Borra, J.P. Deposition of organic coatings at atmospheric pressure from liquid precursors. Plasma Process. Polym. 2007, 4, 360-369. [CrossRef]

37. Heyse, P.; Dams, R.; Paulussen, S.; Houthoofd, K.; Janssen, K.; Jacobs, P.A.; Sels, B.F. Dielectric barrier discharge at atmospheric pressure as a tool to deposit versatile organic coatings at moderate power input. Plasma Process. Polym. 2007, 4, 145-157. [CrossRef]

38. Twomey, B.; Rahman, M.; Byrne, G.; Hynes, A.; O’Hare, L.A.; O’Neill, L.; Dowling, D. Effect of plasma exposure on the chemistry and morphology of aerosol-assisted, plasma-deposited coatings. Plasma Process. Polym. 2008, 5, 737-744. [CrossRef]

39. Leroux, F.; Campagne, C.; Perwuelz, A.; Gengembre, L. Fluorocarbon nano-coating of polyester fabrics by atmospheric air plasma with aerosol. Appl. Surf. Sci. 2008, 254, 3902-3908. [CrossRef]

40. Bour, J.; Bardon, J.; Aubriet, H.; Del Frari, D.; Verheyde, B.; Dams, R.; Vangeneugden, D.; Ruch, D. Different ways to plasma-polymerize HMDSO in DBD configuration at atmospheric pressure for corrosion protection. Plasma Process. Polym. 2008, 5, 788-796. [CrossRef]

41. Beck, A.J.; Short, R.D.; Matthews, A. Deposition of functional coatings from acrylic acid and octamethylcyclotetrasiloxane onto steel using an atmospheric pressure dielectric barrier discharge. Surf. Coat. Technol. 2008, 203, 822-825. [CrossRef]

42. Albaugh, J.; O'Sullivan, C.; O'Neill, L. Controlling deposition rates in an atmospheric pressure plasma system. Surf. Coat. Technol. 2008, 203, 844-847. [CrossRef]

43. Tynan, J.; Ward, P.; Byrne, G.; Dowling, D.P. Deposition of biodegradable polycaprolactone coatings using an in-line atmospheric pressure plasma system. Plasma Process. Polym. 2009, 6, 51-56. [CrossRef]

44. O'Neill, L.; O'Sullivan, C. Polymeric coatings deposited from an aerosol-assisted non-thermal plasma jet. Chem. Vap. Depos. 2009, 15, 21-26. [CrossRef]

45. Bardon, J.; Bour, J.; Del Frari, D.; Arnoult, C.; Ruch, D. Dispersion of cerium-based nanoparticles in an organosilicon plasma polymerized coating: Effect on corrosion protection. Plasma Process. Polym. 2009, 6, 655-659. [CrossRef]

46. O'Neill, L.; Herbert, P.A.F.; Stallard, C.; Dowling, D.P. Investigation of the effects of gas versus liquid deposition in an aerosol-assisted corona deposition process. Plasma Process. Polym. 2010, 7, 43-50. [CrossRef]

47. Nisol, B.; Poleunis, C.; Bertrand, P.; Reniers, F. Poly(ethylene glycol) films deposited by atmospheric pressure plasma liquid deposition and atmospheric pressure plasma-enhanced chemical vapour deposition: Process, chemical composition analysis and biocompatibility. Plasma Process. Polym. 2010, 7, 715-725. [CrossRef] 
48. Heyse, P.; Van Hoeck, A.; Roeffaers, M.B.J.; Raffin, J.P.; Steinbüchel, A.; Stöveken, T.; Lammertyn, J.; Verboven, P.; Jacobs, P.A.; Hofkens, J.; et al. Exploration of atmospheric pressure plasma nanofilm technology for straightforward bio-active coating deposition: Enzymes, plasmas and polymers, an elegant synergy. Plasma Process. Polym. 2011, 8, 965-974. [CrossRef]

49. Herbert, P.A.F.; O’Neill, L.; Jaroszyńska-Wolińska, J.; Stallard, C.P.; Ramamoorthy, A.; Dowling, D.P. A comparison between gas and atomized liquid precursor states in the deposition of functional coatings by pin corona plasma. Plasma Process. Polym. 2011, 8, 230-238. [CrossRef]

50. Dembele, A.; Rahman, M.; Reid, I.; Twomey, B.; MacElroy, J.M.D.; Dowling, D.P. Deposition of hybrid organic-inorganic composite coatings using an atmospheric plasma jet system. J. Nanosci. Nanotechnol. 2011, 11, 8730-8737. [CrossRef]

51. Boscher, N.D.; Choquet, P.; Duday, D.; Kerbellec, N.; Lambrechts, J.C.; Maurau, R. Luminescent lanthanide-based hybrid coatings deposited by atmospheric pressure plasma assisted chemical vapour deposition. J. Mater. Chem. 2011, 21, 18959-18961. [CrossRef]

52. Da Ponte, G.; Sardella, E.; Fanelli, F.; Van Hoeck, A.; d'Agostino, R.; Paulussen, S.; Favia, P. Atmospheric pressure plasma deposition of organic films of biomedical interest. Surf. Coat. Technol. 2011, 205, S525-S528. [CrossRef]

53. Amorosi, C.; Ball, V.; Bour, J.; Bertani, P.; Toniazzo, V.; Ruch, D.; Averous, L.; Michel, M. One step preparation of plasma based polymer films for drug release. Mater. Sci. Eng. C 2012, 32, 2103-2108. [CrossRef]

54. Da Ponte, G.; Sardella, E.; Fanelli, F.; D’Agostino, R.; Gristina, R.; Favia, P. Plasma deposition of PEO-like coatings with aerosol-assisted dielectric barrier discharges. Plasma Process. Polym. 2012, 9, 1176-1183. [CrossRef]

55. Mertz, G.; Fouquet, T.; Becker, C.; Ziarelli, F.; Ruch, D. A methacrylic anhydride difunctional precursor to produce a hydrolysis-sensitive coating by aerosol-assisted atmospheric plasma process. Plasma Process. Polym. 2014, 11, 728-733. [CrossRef]

56. Yang, Y.-W.; Camporeale, G.; Sardella, E.; Dilecce, G.; Wu, J.-S.; Palumbo, F.; Favia, P. Deposition of hydroxyl functionalized films by means of ethylene aerosol-assisted atmospheric pressure plasma. Plasma Process. Polym. 2014, 11, 1102-1111. [CrossRef]

57. Fanelli, F.; Mastrangelo, A.M.; Fracassi, F. Aerosol-assisted atmospheric cold plasma deposition and characterization of superhydrophobic organic-inorganic nanocomposite thin films. Langmuir 2014, 30, 857-865. [CrossRef] [PubMed]

58. Mertz, G.; Fouquet, T.; Ahrach, H.I.E.; Becker, C.; Phan, T.N.T.; Ziarelli, F.; Gigmes, D.; Ruch, D. Water Sensitive Coatings Deposited by Aerosol Assisted Atmospheric Plasma Process: Tailoring the Hydrolysis Rate by the Precursor Chemistry. Plasma Process. Polym. 2015, 12, 1293-1301. [CrossRef]

59. Palumbo, F.; Camporeale, G.; Yang, Y.-W.; Wu, J.-S.; Sardella, E.; Dilecce, G.; Calvano, C.D.; Quintieri, L.; Caputo, L.; Baruzzi, F.; et al. Direct Plasma Deposition of Lysozyme-Embedded Bio-Composite Thin Films. Plasma Process. Polym. 2015, 12, 1302-1310. [CrossRef]

60. Profili, J.; Levasseur, O.; Naudé, N.; Chaneac, C.; Stafford, L.; Gherardi, N. Influence of the voltage waveform during nanocomposite layer deposition by aerosol-assisted atmospheric pressure Townsend discharge. J. Appl. Phys. 2016, 120, 053302. [CrossRef]

61. Profili, J.; Levasseur, O.; Blaisot, J.B.; Koronai, A.; Stafford, L.; Gherardi, N. Nebulization of Nanocolloidal Suspensions for the Growth of Nanocomposite Coatings in Dielectric Barrier Discharges. Plasma Process. Polym. 2016, 13, 981-989. [CrossRef]

62. Liguori, A.; Traldi, E.; Toccaceli, E.; Laurita, R.; Pollicino, A.; Focarete, M.L.; Colombo, V.; Gherardi, M. Co-Deposition of Plasma-Polymerized Polyacrylic Acid and Silver Nanoparticles for the Production of Nanocomposite Coatings Using a Non-Equilibrium Atmospheric Pressure Plasma Jet. Plasma Process. Polym. 2016, 13, 623-632. [CrossRef]

63. Pignatelli, D.; Sardella, E.; Palumbo, F.; Lo Porto, C.; Taccola, S.; Greco, F.; Mattoli, V.; Favia, P. Plasma assisted deposition of free-standing nanofilms for biomedical applications. Plasma Process. Polym. 2016, 13, 1224-1229. [CrossRef]

64. Hsiao, C.-P.; Wu, C.-C.; Liu, Y.-H.; Yang, Y.-W.; Cheng, Y.-C.; Palumbo, F.; Camporeale, G.; Favia, P.; Wu, J.-S. Aerosol-Assisted Plasma Deposition of Biocomposite Coatings: Investigation of Processing Conditions on Coating Properties. IEEE Trans. Plasma Sci. 2016, 44, 3091-3098. [CrossRef] 
65. Moreno-Couranjou, M.; Mauchauffé, R.; Bonot, S.; Detrembleur, C.; Choquet, P. Anti-biofouling and antibacterial surfaces: Via a multicomponent coating deposited from an up-scalable atmospheric-pressure plasma-assisted CVD process. J. Mater. Chem. B 2018, 6, 614-623. [CrossRef]

66. Czuba, U.; Quintana, R.; Lassaux, P.; Bombera, R.; Ceccone, G.; Bañuls-Ciscar, J.; Moreno-Couranjou, M.; Detrembleur, C.; Choquet, P. Anti-biofouling activity of Ranaspumin-2 bio-surfactant immobilized on catechol-functional PMMA thin layers prepared by atmospheric plasma deposition. Colloids Surf. B Biointerfaces 2019, 178, 120-128. [CrossRef]

67. O'Neill, L.; Dobbyn, P.; Kulkarni, M.; Pandit, A. Wound healing using plasma modified collagen. Clin. Plasma Med. 2018, 12, 23-32. [CrossRef]

68. O'Neill, L.; O'Sullivan, D.; Fourkas, M.; Tartaglia, J. Evaluation of the J-Plasma Electrosurgical Device Combined with Nebulized Collagen for Burn Healing in Rodents. Plasma Med. 2018, 8, 365-377. [CrossRef]

69. O'sullivan, D.; McArdle, H.; O'Reilly, J.A.; O'Kennedy, R.J.; Forster, R.; O'Neill, L. Plasma deposition of collagen for cell-culture applications. Plasma Process. Polym. 2020, 17, 1900147. [CrossRef]

70. Liu, Y.H.; Yang, C.H.; Lin, T.R.; Cheng, Y.C. Using aerosol-assisted atmospheric-pressure plasma to embed proteins onto a substrate in one step for biosensor fabrication. Plasma Process. Polym. 2018, 15, 1800001. [CrossRef]

71. Barletta, F.; Liguori, A.; Leys, C.; Colombo, V.; Gherardi, M.; Nikiforov, A. Novel method for NH-rich coatings engineering by means of aerosol assisted atmospheric pressure plasma deposition. Mater. Lett. 2018, 214, 76-79. [CrossRef]

72. Palumbo, F.; Treglia, A.; Lo Porto, C.; Fracassi, F.; Baruzzi, F.; Frache, G.; El Assad, D.; Pistillo, B.R.; Favia, P. Plasma-Deposited Nanocapsules Containing Coatings for Drug Delivery Applications. ACS Appl. Mater. Interfaces 2018, 10, 35516-35525. [CrossRef] [PubMed]

73. Lo Porto, C.; Palumbo, F.; Palazzo, G.; Favia, P. Direct plasma synthesis of nano-capsules loaded with antibiotics. Polym. Chem. 2017, 8, 1746-1749. [CrossRef]

74. Lo Porto, C.; Palumbo, F.; Buxadera-Palomero, J.; Canal, C.; Jelinek, P.; Zajickova, L.; Favia, P. On the plasma deposition of vancomycin-containing nano-capsules for drug-delivery applications. Plasma Process. Polym. 2018, 15, 1700232. [CrossRef]

75. Lo Porto, C.; Palumbo, F.; Fracassi, F.; Barucca, G.; Favia, P. On the formation of nanocapsules in aerosol-assisted atmospheric-pressure plasma. Plasma Process. Polym. 2019, 16, 1900116. [CrossRef]

76. Chen, X.; Lo Porto, C.; Chen, Z.; Merenda, A.; Allioux, F.M.; d'Agostino, R.; Magniez, K.; Dai, X.J.; Palumbo, F.; Dumée, L.F. Single step synthesis of Janus nano-composite membranes by atmospheric aerosol plasma polymerization for solvents separation. Sci. Total Environ. 2018, 645, 22-33. [CrossRef]

77. Mertz, G.; Delmée, M.; Bardon, J.; Martin, A.; Ruch, D.; Fouquet, T.; Garreau, S.; Airoudj, A.; Marguier, A.; Ploux, L.; et al. Atmospheric pressure plasma co-polymerization of two acrylate precursors: Toward the control of wetting properties. Plasma Process. Polym. 2018, 15, 1800073. [CrossRef]

78. Duran, I.; Profili, J.; Stafford, L.; Laroche, G. Unveiling the origin of the anti-fogging performance of plasma-coated glass: Role of the structure and chemistry of siloxane precursors. Prog. Org. Coat. 2020, 141, 105401. [CrossRef]

79. Durán, I.R.; Profili, J.; Stafford, L.; Laroche, G. Beyond microelectronics with 1,3,5,7-tetramethylcyclotetrasiloxane: A promising molecule for anti-fogging coatings. Mater. Chem. Phys. 2020, 242, 122508. [CrossRef]

80. Jalaber, V.; Del Frari, D.; De Winter, J.; Mehennaoui, K.; Planchon, S.; Choquet, P.; Detrembleur, C.; Moreno-Couranjou, M. Atmospheric aerosol assisted pulsed plasma polymerization: An environmentally friendly technique for tunable catechol-bearing thin films. Front. Chem. 2019, 7, 183. [CrossRef] [PubMed]

81. Boscher, N.D.; Duday, D.; Heier, P.; Heinze, K.; Hilt, F.; Choquet, P. Plasma Polymer Membranes for Immobilising Metalloporphyrins. Plasma Process. Polym. 2013, 10, 336-344. [CrossRef]

82. Francescangeli, A.; Palumbo, F.; d'Agostino, R.; Defranoux, C. Pulsed plasma deposition from vinyltrimethylsilane/oxygen mixtures. Plasma Process. Polym. 2009, 6, 132-138. [CrossRef]

83. Tatoulian, M.; Arefi-Khonsari, F.; Tatoulian, L.; Amouroux, J.; Borra, J.P. Deposition of poly(acrylic acid) films by electrohydrodynamic atomization in postdischarge at atmospheric pressure in air. Chem. Mater. 2006, 18, 5860-5863. [CrossRef]

84. Donegan, M.; Dowling, D.P. Protein adhesion on water stable atmospheric plasma deposited acrylic acid coatings. Surf. Coat. Technol. 2013, 234, 53-59. [CrossRef] 
85. Carton, O.; Salem, D.B.; Pulpytel, J.; Arefi-Khonsari, F. Improvement of the water stability of plasma polymerized acrylic acid/MBA coatings deposited by atmospheric pressure air plasma jet. Plasma Chem. Plasma Process. 2015, 35, 819-829. [CrossRef]

86. Stallard, C.P.; Solar, P.; Biederman, H.; Dowling, D.P. Deposition of Non-Fouling PEO-Like Coatings Using a Low Temperature Atmospheric Pressure Plasma Jet. Plasma Process. Polym. 2016, 13, 241-252. [CrossRef]

87. Coclite, A.M.; Milella, A.; Palumbo, F.; Fracassi, F.; D'Agostino, R. Chemical and morphological characterization of low-k dielectric films deposited from hexamethyldisiloxane and ethylene RF Glow discharges. Plasma Process. Polym. 2010, 7, 1022-1029. [CrossRef]

88. Wei, G.; Varghese, S.; Beaman, K.; Vasilyeva, I.; Mendiola, T.; Carswell, A.; Fillmore, D.; Lu, S. A comprehensive study on nanomechanical properties of various $\mathrm{SiO}$ 2-based dielectric films. In Proceedings of the WMED 2010 - 8th IEEE Workshop on Microelectronics and Electron Devices, Boise, ID, USA, 16 April 2010.

89. Creatore, M.; Palumbo, F.; D'Agostino, R.; Fayet, P. RF plasma deposition of SiO2-like films: Plasma phase diagnostics and gas barrier film properties optimisation. Surf. Coat. Technol. 2001, 142, 163-168. [CrossRef]

90. Palumbo, F.; D’Agostino, R.; Fracassi, F.; Laera, S.; Milella, A.; Angelini, E.; Grassini, S. On low pressure plasma processing for metal protection. Plasma Process. Polym. 2009, 6, S684-S689. [CrossRef]

91. Di Mundo, R.; Palumbo, F.; D’Agostino, R. Nanotexturing of polystyrene surface in fluorocarbon plasmas: From sticky to slippery superhydrophobicity. Langmuir 2008, 24, 5044-5051. [CrossRef] [PubMed]

92. Ellinas, K.; Tserepi, A.; Gogolides, E. Superhydrophobic, passive microvalves with controllable opening threshold: Exploiting plasma nanotextured microfluidics for a programmable flow switchboard. Microfluid. Nanofluid. 2014, 17, 489-498. [CrossRef]

93. Garzia Trulli, M.; Claes, N.; Pype, J.; Bals, S.; Baert, K.; Terryn, H.; Sardella, E.; Favia, P.; Vanhulsel, A. Deposition of aminosilane coatings on porous $\mathrm{Al}_{2} \mathrm{O}_{3}$ microspheres by means of dielectric barrier discharges. Plasma Process. Polym. 2017, 14, 1600211. [CrossRef]

94. Lee, H.-T.; Lin, L.-H. Waterborne Polyurethane/Clay Nanocomposites: Novel Effects of the Clay and Its Interlayer Ions on the Morphology and Physical and Electrical Properties. Macromolecules 2006, 39, 6133-6141. [CrossRef]

95. Wang, Y.; Lim, S.; Luo, J.L.; Xu, Z.H. Tribological and corrosion behaviors of Al2O3/polymer nanocomposite coatings. Wear 2006, 260, 976-983. [CrossRef]

96. Du, X.W.; Fu, Y.S.; Sun, J.; Han, X.; Liu, J. Complete UV emission of ZnO nanoparticles in a PMMA matrix. Semicond. Sci. Technol. 2006, 21, 1202-1206. [CrossRef]

97. Chau, J.L.H.; Tung, C.T.; Lin, Y.M.; Li, A.K. Preparation and optical properties of titania/epoxy nanocomposite coatings. Mater. Lett. 2008, 62, 3416-3418. [CrossRef]

98. Bozzi, A.; Yuranova, T.; Kiwi, J. Self-cleaning of wool-polyamide and polyester textiles by TiO2-rutile modification under daylight irradiation at ambient temperature. J. Photochem. Photobiol. A Chem. 2005, 172, 27-34. [CrossRef]

99. Ma, C.-C.M.; Chen, Y.-J.; Kuan, H.-C. Polystyrene nanocomposite materials-Preparation, mechanical, electrical and thermal properties, and morphology. J. Appl. Polym. Sci. 2006, 100, 508-515. [CrossRef]

100. Boccaccini, A.R.; Erol, M.; Stark, W.J.; Mohn, D.; Hong, Z.; Mano, J.F. Polymer/bioactive glass nanocomposites for biomedical applications: A review. Compos. Sci. Technol. 2010, 70, 1764-1776. [CrossRef]

101. Satarkar, N.S.; Biswal, D.; Hilt, J.Z. Hydrogel nanocomposites: A review of applications as remote controlled biomaterials. Soft Matter 2010, 6, 2364-2371. [CrossRef]

102. Profili, J.; Levasseur, O.; Koronai, A.; Stafford, L.; Gherardi, N. Deposition of nanocomposite coatings on wood using cold discharges at atmospheric pressure. Surf. Coat. Technol. 2017, 309, 729-737. [CrossRef]

103. Fanelli, F.; Mastrangelo, A.M.; De Vietro, N.; Fracassi, F. Preparation of multifunctional superhydrophobic nanocomposite coatings by aerosol-assisted atmospheric cold plasma deposition. Nanosci. Nanotechnol. Lett. 2015, 7, 84-88. [CrossRef]

104. Fanelli, F.; Fracassi, F. Aerosol-assisted atmospheric pressure cold plasma deposition of organic-inorganic nanocomposite coatings. Plasma Chem. Plasma Process. 2014, 34, 473-487. [CrossRef]

105. Mao, C.; Liu, A.; Cao, B. Virus-Based Chemical and Biological Sensing. Angew. Chem. Int. Ed. 2009, 48, 6790-6810. [CrossRef]

106. Magliulo, M.; Mallardi, A.; Mulla, M.Y.; Cotrone, S.; Pistillo, B.R.; Favia, P.; Vikholm-Lundin, I.; Palazzo, G.; Torsi, L. Electrolyte-Gated Organic Field-Effect Transistor Sensors Based on Supported Biotinylated Phospholipid Bilayer. Adv. Mater. 2013, 25, 2090-2094. [CrossRef] 
107. Lisboa, P.; Villiers, M.B.; Brakha, C.; N Marche, P.; Valsesia, A.; Colpo, P.; Rossi, F. Fabrication of Bio-Functionalised Polypyrrole Nanoarrays for Bio-Molecular Recognition. Micro Nanosyst. 2011, 3, 83-89. [CrossRef]

108. Hetrick, E.M.; Schoenfisch, M.H. Reducing implant-related infections: Active release strategies. Chem. Soc. Rev. 2006, 35, 780-789. [CrossRef] [PubMed]

109. Heuts, J.; Salber, J.; Goldyn, A.M.; Janser, R.; Möller, M.; Klee, D. Bio-functionalized star PEG-coated PVDF surfaces for cytocompatibility-improved implant components. J. Biomed. Mater. Res. Part A 2010, 92, 1538-1551. [CrossRef] [PubMed]

110. Mohorčič, M.; Jerman, I.; Zorko, M.; Butinar, L.; Orel, B.; Jerala, R.; Friedrich, J. Surface with antimicrobial activity obtained through silane coating with covalently bound polymyxin B. J. Mater. Sci. Mater. Med. 2010, 21, 2775-2782. [CrossRef] [PubMed]

111. Faure, E.; Falentin-Daudré, C.; Lanero, T.S.; Vreuls, C.; Zocchi, G.; Van De Weerdt, C.; Martial, J.; Jérôme, C.; Duwez, A.-S.; Detrembleur, C. Functional Nanogels as Platforms for Imparting Antibacterial, Antibiofilm, and Antiadhesion Activities to Stainless Steel. Adv. Funct. Mater. 2012, 22, 5271-5282. [CrossRef]

112. Vreuls, C.; Zocchi, G.; Vandegaart, H.; Faure, E.; Detrembleur, C.; Duwez, A.S.; Martial, J.; Van De Weerdt, C. Biomolecule-based antibacterial coating on a stainless steel surface: Multilayer film build-up optimization and stability study. Biofouling 2012, 28, 395-404. [CrossRef]

113. Heyse, P.; Roeffaers, M.B.J.; Paulussen, S.; Hofkens, J.; Jacobs, P.A.; Sels, B.F. Protein immobilization using atmospheric-pressure dielectric-barrier discharges: A route to a straightforward manufacture of bioactive films. Plasma Process. Polym. 2008, 5, 186-191. [CrossRef]

114. Porto, C.L.; Palumbo, F.; Treglia, A.; Camporeale, G.; Favia, P. Aerosol assisted atmopheric pressure PE-CVD of drug containing nano-capsules. Jpn. J. Appl. Phys. 2019, 59, SA0801. [CrossRef]

(C) 2020 by the authors. Licensee MDPI, Basel, Switzerland. This article is an open access article distributed under the terms and conditions of the Creative Commons Attribution (CC BY) license (http://creativecommons.org/licenses/by/4.0/). 